University of Pennsylvania Carey Law School

Penn Law: Legal Scholarship Repository

Faculty Scholarship at Penn Law

1999

\title{
On the Obligation of the State to Extend a Right of Self-Defense to its Citizens
}

Claire Oakes Finkelstein

University of Pennsylvania Carey Law School

Follow this and additional works at: https://scholarship.law.upenn.edu/faculty_scholarship

Part of the Criminal Law Commons, Criminal Procedure Commons, Ethics and Political Philosophy Commons, Jurisprudence Commons, Law and Society Commons, Legal History Commons, Legal Theory Commons, and the Social Policy Commons

\section{Repository Citation}

Finkelstein, Claire Oakes, "On the Obligation of the State to Extend a Right of Self-Defense to its Citizens" (1999). Faculty Scholarship at Penn Law. 1005.

https://scholarship.law.upenn.edu/faculty_scholarship/1005

This Article is brought to you for free and open access by Penn Law: Legal Scholarship Repository. It has been accepted for inclusion in Faculty Scholarship at Penn Law by an authorized administrator of Penn Law: Legal Scholarship Repository. For more information, please contact PennlawIR@law.upenn.edu. 


\title{
ON THE OBLIGATION OF THE STATE TO EXTEND A RIGHT OF SELF-DEFENSE TO ITS CITIZENS
}

\author{
CLAIRE OAKES FINKELSTEIN ${ }^{\dagger}$
}

\section{INTRODUCTION}

A certain way of arguing for legal rights is common in liberal political discourse. It suggests that the State is obligated to extend a given right to its citizens, based on their possession of a parallel, or closely related, moral right. Someone might argue for a legal right to abortion, for example, by claiming that women have a prior moral right to make choices concerning their bodies. Or someone might argue for a private club's entitlement to restrict its membership by saying that people have a right to associate in their private lives with whomever they wish. ' This way of arguing has also historically been used to evaluate existing legal regimes more generally. It was, for example, the charge of the American Declaration of Independence against the British that all men have certain rights, such as the right to life, liberty, and the pursuit of happiness, that the Crown had failed to respect. ${ }^{2}$ It was no less prevalent in the rhetoric of the French Revolution, where the French monarchy's indifference to a supposed set of natural rights was a way of describing its transgressions against the French people. More recently, the Preamble to the United Nation's Universal Declaration of Human Rights asserts that the "recognition of the ... inalienable rights of all members of the human family is the foundation of freedom, justice and

$†$ Rockefeller Fellow, University Center for Human Values, Princeton University (199899); Acting Professor of Law, University of Califormia, Berkeley. I wish to thank Larry Alexander, Marcia Baron, Meir Dan-Cohen, Peter Detre, David Gauthier, Ruth Gavison, Sanford Kadish, Leo Katz, Phil Montague, Connie Rosati, Sam Scheffler and Alan Wertheimer for their helpful comments on various drafts. I also wish to thank Kim Kempton for her assistance with research.

1 The fact that abortion and free association are also constitutional rights is not relevant here, because the argument is frequently made to support nonconstitutional rights as well. A version of it has even been used to support laws restricting cruelty to animals, on the grounds that animals have moral rights that the State is bound to respect. See ANIMAL RIGHTS AND Human Obligations 105-38 (Tom Regan \& Peter Singer eds., 2d ed. 1989).

2 THE DECLARATION OF INDEPENDENCE para. 2 (U.S. 1776). Some constitutional scholars claim that certain constitutional provisions were meant to incorporate the natural rights of citizens. See Charles L. Black, JR., A New BIRTH of FreEdom: Human Rights, NAMED AND UNNAMED 5-40 (1997) (arguing that the Framers intended the Ninth Amendment, among others, to refer to a set of natural rights they conceived citizens as possessing). 
peace in the world," and the document proceeds to offer a list of specific entitlements designed to provide a standard for assessing the domestic law of all nations. ${ }^{3}$

The traditional attack on this way of arguing is to reject the idea of natural or "extrapolitical" moral rights altogether. Ever since natural rights reached sufficient prominence to enter mainstream political thought, they have been greeted by a chorus of skeptics who reject the idea that the rights human beings have in civil society can be meaningfully assessed by comparing them to a set of entitlements human beings may have in an imaginary natural condition. ${ }^{4}$ Jeremy Bentham, for example, famously called the idea of natural rights "nonsense upon stilts." Edmund Burke, rejecting the rhetoric of rights so beloved by the French revolutionaries, insisted that the rights of man are a matter "to be settled by convention," rather than by theory. ${ }^{6}$ Karl Marx wrote derisively about the "so-called rights of man," which he thought reflected the bourgeois view of man as "an individual withdrawn behind his private interests and whims and separated from the community.",

It is difficult to know how to begin to resolve this kind of ontological dispute, as any debate between the rights theorist and the skeptic seems likely to devolve into a battle of intuitions. One is left simply to choose up sides, accepting or rejecting the political conclusions accordingly. If we reflect carefully on the move from moral to legal rights, however, a different query emerges, one that shows more promise of being resolved by argument than is the debate with the skeptic. Even if we concede the existence of extrapolitical moral rights, what relevance do they have for the legal rights of citizens? After all, there is no entailment from a premise like

Human beings have a moral right to $X$

to a conclusion like

Human beings should have a legal right to $X$

or

The State has an obligation to extend a legal right to $X$.

${ }^{3}$ Universal Declaration of Human Rights, G.A. Res. 217(III)(A), U.N. Doc. A/810, at 71 (1948).

${ }^{4}$ While someone might wish to argue for a set of extrapolitical, moral rights that are not natural, the traditional contrast is between the rights human beings have in civil society and the rights they have in nature.

5 JEREMY BENTHAM, Anarchical Fallacies, in THE WORKS OF JEREMY BENTHAM 489 , 501 (John Bowring ed., Russel \& Russel 1962) (1838-1843).

6 EDMUND BuRKe, REFlections ON THE REvolution IN FRANCE 67 (Thomas H.D. Mahoney ed., The Liberal Arts Press 1955) (1790).

${ }^{7}$ Karl MarX, On the Jewish Question, in KARL MARX: Selected Writings 39, 54 (David McLellan ed., Oxford Univ. Press 1977) (circa 1843). 
We are accustomed to hearing statements of the first sort as providing a reason for statements of the second sort. Upon further reflection, however, it is not clear why this should be so. Why would the moral rights of citizens place the State under an obligation, and what could the nature of that obligation be? Is it a moral obligation? Or is the obligation based on political considerations, such as those that bear on a State's legitimacy?

Inattention to the gap between moral and ideal legal rights is not limited to ordinary political discourse. Contemporary moral philosophers contribute to the tendency by focusing exclusively on the parameters of various moral rights and failing to trace the implications of these rights for civil society. Presumably they are not indifferent to the political implications of the moral rights for which they argue. More likely, moral philosophers also assume the political relevance of such rights. If we were to consider the move from moral to legal rights more carefully, however, any such assumption would appear unwarranted.

In this Article, I address the relation between moral and legal rights in the context of the right to self-defense. I suggest that even when the right to self-defense is conceived in its strongest form, it is not easily shown that the State is obligated to respect conduct in its exercise. Although I focus on one particular right, I suspect that a number of the other moral rights that liberal political thinkers use to argue for corresponding legal rights would be subject to the same difficulty. ${ }^{8}$ I do not, however, attempt to establish this broader claim here.

In Part I, I consider a way of establishing the relevance of the moral right to self-defense for the corresponding legal right that seems consistent with liberal rights discourse. This account would make use of a standard feature of rights in the philosophical literature, namely that rights impose duties on other agents. In the case of self-defense, the relevant duties are duties of noninterference. It follows that the State may not forbid acts of self-defense, since this would constitute interference with the moral right its citizens have to perform them. The State's obligation to extend a legal right of self-defense to its citizens, on this account, is based on a more general obligation to respect the moral rights individuals have. I call this the "Moral Obligation Argument."

A difficulty with this way of arguing, however, stems from the fact that the right to self-defense is subject to conflict with other instances of the

${ }^{8}$ More specifically, I suspect that moral rights to do or to refrain from doing things have only weak implications for their corresponding legal rights. Property rights, by contrast, seem better suited to the picture ordinary rights discourse and moral philosophers have in mind. Even then, the picture is not free from difficulties. See discussion infra at notes 35-38 (presenting a contradictory example). 
right, and that in these cases the duty of noninterference does not necessarily hold. Of particular importance is the position of third parties in the face of a conflict between two equally entitled self-defenders: the question is whether a third party may intervene on one side or the other of such a conflict or whether she remains subject to the duty of noninterference which the right to self-defense normally imposes. Part II argues that the fact that each party to the conflict is acting from a claim of right does not obligate a third party to stay out of the fray. If this is correct, the Moral Obligation Argument must be abandoned.

Part III considers a possible strategy for rescuing the foregoing way of moving from the moral to the legal right to self-defense. One could shrink the scope of the moral right, reducing it to those instances in which the right is not subject to conflict. It would then be possible to preserve the idea that the State is under a duty of noninterference for some instances, even if it must be relinquished for others. I argue, however, that the shrunken picture of the right to self-defense is not a plausible one and that a unified treatment allows for a more compelling account. The possibility of conflicts of right in one class of cases thus puts pressure on the view that the right imposes duties of noninterference in other cases.

In light of the foregoing difficulties, I suggest that the moral right to self-defense is better understood as a moral permission to favor one's own life over the life of another than as a right, as moral philosophers would hold. Moral permissions, unlike rights, allow others to interfere with the exercise of the entitlement, provided that the act of interference is permissible on other grounds. If self-defense is a mere permission, the question whether the State should extend a right of self-defense to its citizens cannot be answered by pointing to the underlying moral entitlement and saying that the State has a duty to respect it. This leaves the problem of whether the State must respect the entitlement unresolved.

As we see in Part IV, there is historical precedent for conceiving of selfdefense as a mere permission rather than as a right. Thomas Hobbes and Saint Thomas Aquinas, for example, both treat the entitlement in this way. Crucial for our purposes is that neither thinks the entitlement irrelevant for establishing a corresponding legal right. Each, in different ways, attempts to show that the underlying moral entitlement ultimately does supply a reason to think the State obligated to extend a corresponding legal right. Unfortunately, however, secular political philosophy cannot adopt either approach in its entirety, for each depends on the idea that states can owe duties to God. Accordingly, in Part V, I reconsider the question Hobbes and Aquinas address. I argue that a secular account of the State's obligation to extend a right of self-defense to its citizens must be sought not in moral 
philosophy, but in the substantive political considerations that establish state legitimacy. In this Article, I can only suggest the shape that such an account would take. My hope is that the Article will at least help to revive the political dimension of the problem of self-defense, a dimension that has been largely lost in contemporary discussions of the right.

\section{CONFLICTS OF RIGHT}

When philosophers assert the existence of a moral right to self-defense, they mean that a person defending her life or bodily integrity under certain circumstances has a basis for demanding that others respect her entitlement to do so. The point is a standard one about the nature of rights: to say that someone has a right implies that others have various obligations arising from the existence of the right. ${ }^{9}$ In the terminology often used, the entitlement to defend one's life with force is thought of as a "claim right." The distinguishing mark of claim rights, as opposed to "liberties" or "liberty rights," is that they are correlative with duties. ${ }^{10}$ If self-defense is a claim right, we would like to know what kind of duties correlate with it, and who bears these duties. The most common duty associated with self-defense is a duty not to interfere with the exercise of the right, ${ }^{11}$ a duty borne by the entire world. ${ }^{12}$ Thus, if I have a right to defend myself with the use of lethal force and I have a gun, it is not permissible for anyone to interfere with my self-protection, say, by removing the bullets or by disabling me from pulling the trigger. Similarly, if I am defending myself against an aggressor, it should not be permissible for someone to render him assistance. Among

9 This way of thinking about rights is most often associated with Hohfeld's discussion of legal rights. See WeSLEY NewCOMB HohfELd, FundAMENTAL LEgAL CONCEPTIONS 36 (1919) (calling "right" and "duty" "jural correlatives"). It has become the predominant way of thinking about moral rights as well. See JUDITH JARVIS THOMSON, THE REALM OF RIGHTS 39 (1990) (applying the Hohfeldian idea of rights as correlative with duties to moral rights).

${ }^{10}$ Hohfeld does not say that rights are "claim rights," but he does explain the notion of a right as a kind of claim. See HOHFELD, supra note 9, at 38 ("If . . we should seek a synonym for the term 'right' . . perhaps the word 'claim' would prove the best."). The expression "claim right" is generally preferable to "right," because some philosophers, such as Hobbes, use the term "right" to refer to what Hohfeld would call a "liberty" or "privilege." See infra Part IV (discussing pre-modern approaches to the legal right of self-defense). To avoid ambiguity, I shall distinguish "claim rights" from "liberty rights."

11 As Thomson writes, if $X$ is trying to defend life and limb, $Y$ "infringe[s] a claim of X's if Y interferes." THOMSON, supra note 9, at 280.

${ }_{12}$ To be more precise, we could say, as Hohfeld does, that there is no such thing as a right against the whole world. As he says, "the supposed single right in rem correlating with 'a duty' on 'all' persons really involves as many separate and distinct 'right-duty' relations as there are persons subject to a duty." HOHFELD, supra note 9, at 94. 
other things, this would be a way of interfering with my exercise of the right to self-defense. ${ }^{13}$

The claim-right picture of the right to self-defense suggests a way of accounting for the move from the moral to the legal right. While the argument is usually not made explicitly, ${ }^{14}$ it follows naturally from the foregoing view of rights. It also seems to provide a compelling way to explain the move from moral to legal rights, given the assumptions of liberal political theory. ${ }^{15}$ The argument would run as follows. If I have a right to selfdefense, others have a duty to refrain from impeding my right to selfdefense or even from doing anything that would make it more difficult for me to defend myself. This duty extends both to my attacker and to third parties who might seek to intervene. If I am exercising a right to selfdefense against you, for example, you have a duty not to oppose my use of force. Similarly, a third party observing the conflict has a duty to refrain from assisting my opponent or from placing obstacles in my way.

There is no reason to suppose the State, as a third party, would be in any different position from an ordinary citizen in this regard. It would be impermissible, for example, for a police officer to interfere with my efforts to defend myself, at least if not done in the service of defending me himself. One way the State can create an obstacle to a person's exercise of the right to self-defense is to threaten to punish him for assaulting or killing another in his own defense. ${ }^{16}$ In this sense, we can think of the State as a shadow

${ }^{13}$ A right to self-defense can on occasion generate more specific duties, such as a duty of assistance. If you have a gun that I could use to defend myself against an attack, for example, you may have a duty to let me use it, at least if it is no great hardship for you to do so.

14 Perhaps the clearest articulation of this view appears in RONALD DWORKIN, TAKING RIGHTS SERIOUSLY 184-91 (1977), which explains that the view that citizens have moral rights against their governments implies that government does wrong if it does not respect these rights in law. Another version of this thesis is presented by Henry Shue, who begins his book with the statement: "A moral right provides ... the rational basis for a justified demand ... that the actual enjoyment of a substance be . . . socially guaranteed ...." HENRY

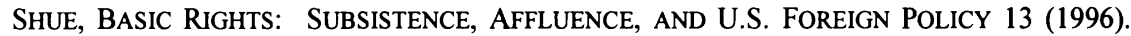
Later he explains that the fact that rights must be socially guaranteed is what imposes duties on the State to protect moral rights.

${ }^{15}$ I do not mean to suggest that the account I am about to offer supplies the only possible way of moving from moral to legal rights. On a Hegelian account of the notion of a right, for example, the move would be made quite differently. See Ernest J. Weinrib, Right and Advantage in Private Law, 10 CARDOZO L. REV. 1283 (1989) (exploring Hegel's notion of abstract right). I do wish to suggest, however, that it is the best account of this move that is consistent with basic liberal presuppositions.

${ }^{16}$ Someone might wish to question whether the State would indeed interfere with the right to self-defense by outlawing it. After all, a person need not refrain from defending her life simply because she might later be subject to punishment for it. So in what sense would punishing acts of self-defense interfere with them? First, the interference in question is interference with the exercise of a right, and making self-defense illegal would do that, because it 
third party to the exercise of a first party's right of self-defense in civil society, since the State is always in a position to intervene with the exercise of the right through legislation. Under the claim-right picture of self-defense, then, the State has a duty to permit self-defensive conduct because such conduct constitutes the exercise of a moral right. This way of defending the move from the moral to the legal right is what I am calling the "Moral Obligation Argument."

Sensible as the Moral Obligation Argument may seem, I shall suggest that someone who seeks to defend the move from the moral to the legal right to self-defense in this way will encounter a dilemma: either she must settle for an implausible account of the right in order to preserve the Moral Obligation Argument, or she must sacrifice this way of accounting for the move from the moral to the legal right by abandoning the view that the right imposes duties of noninterference on third parties. On the former strategy, the account of the right to self-defense will be unconvincing. On the latter, we lose an appealing reason for thinking the existence of a moral right to self-defense compels the extension of the corresponding legal right, and it is not readily apparent what other argument we can put in its place.

The source of the difficulty is the fact that individuals have a right to defend themselves against innocent attackers as well as against culpable ones. But when the right is exercised against innocents there can be no general duty of noninterference. It follows that the Moral Obligation Argument fails where the exercise of the right against innocents is concerned. The State's duty to respect the moral right on the foregoing picture must be limited to the exercise of the right against culpable aggressors. Hence the dilemma: either one must distort the account of the moral right by limiting it to a right exercised against culpable aggressors, or one must abandon the claim that the moral right to self-defense places the State under a duty of noninterference.

The modern view of rights as imposing duties arguably entered the philosophical landscape with Locke. ${ }^{17}$ Unlike Hobbes, Locke sees the state

would create a countervailing duty to refrain from performing self-defensive acts. Second, it does not quite seem correct to say that forbidding self-defense would not interfere with a person's ability to defend himself, at least if the person is rational. For the State can always authorize punishment that is worse than the consequences of not defending oneself. This would constitute interference in the same way that punishing robbery interferes with a person's ability to rob. For beating one's attacker, for example, the State could authorize death, and for killing one's attacker, it could authorize torture and then death.

17 See A. JOHN SIMMONS, THE LOCKEAN THEORY OF RIGHTS 71-73 (1992) (arguing that Locke's primary conception of right is that of claim right). Simmons, however, suggests that Locke may have gotten the notion originally from Puffendorf. See id. at 73. But see A.I. MELDEN, RIGHTS AND PERSONS 230-31 (1977) (noting that Locke ushered in the modem the- 
of nature as a condition of limited entitlement. The Law of Nature mandates not only self-preservation, but also that "no one ought to harm another in his life, health, liberty, or possessions."18 Natural rights are not infinite; they are constrained by their own identity as sources of limitation on the harm it is permissible to inflict on others. The Moral Obligation Argument fits nicely with a Lockean conception of rights, because natural rights on this view impose restrictions on the powers of the State in civil society.

It should not be surprising, then, that the difficulty with innocent aggressors first becomes evident in Locke's own discussion of the right to self-defense. Locke thinks a person who expresses a "settled design upon another man's life, puts him in a state of war with him against whom he has declared such an intention." 19 The reason for this is that the victim's right to life imposes a duty of noninterference on the attacker, which he violates by threatening to kill the victim. The familiar problem Locke's account raises is how it can be permissible for a person to kill his assailant, given that the assailant also has rights that he is bound to respect. Locke's answer is that assailants "are not under the ties of the commonlaw of reason," and that they "have no other rule, but that of force and violence, and so may be treated as beasts of prey." 20 By attacking, an aggressor forfeits his right to life. In the absence of such a right, an aggressor may be treated like an animal-that is, he may be hunted down and killed.

It is awkward, however, to suppose that an innocent aggressor places himself in a state of war with the one he attacks. Consider a young child who forms no malicious intentions or a person who reasonably but mistakenly thinks he is defending his own life. Is it plausible to suppose that merely by endangering the life of another, the innocent aggressor strips herself of the rights that distinguish her from the beasts? The difficulty with innocent aggressors becomes even more acute when we consider Locke's suggestion that the right to self-defense is an instance of the natural right men have "to judge of, and punish the breaches of that law in others ... in crimes where the heinousness of the fact... requires it."21 Surely children and the insane do not merit punishment for attacking someone if their condition defeats responsibility for their actions.

Contemporary "Lockeans" are fortunately more aware of the difficulty than Locke was, and they have taken up the challenge to his account. Judith

ory of rights); 'NONSENSE UPON STILTS': BENTHAM, BURKE AND MARX ON THE RIGHTS OF MAN 7 (Jeremy Waldron ed., 1987) (describing Locke as introducing modern rights theory).

18 JOHN LOCKE, SECOND TREATISE OF GOVERNMENT § 6 (C.B. Macpherson ed., Hackett Publ'g Co. 1980) (1690).

19 Id. § 16.

${ }^{20} \mathrm{Id}$.

${ }^{21}$ Id. $\S 87$. 
Thomson, for example, has attempted to show that the forfeiture of right on the part of an aggressor does not depend on his culpability. Indeed, she argues that someone who poses a threat to your life need not even be aggressing against you in order for him to have forfeited the rights that would otherwise make it impermissible for you to kill him. ${ }^{22}$ All that is necessary, she suggests, is that the person threatening your life will otherwise kill you if you do not kill him. ${ }^{23}$ By killing you, a person infringes your right not to be killed by him. It is thus permissible for you to kill someone who would otherwise kill you, to prevent the infringement of your right not to be killed by him. Unlike Locke, Thomson provides the correct intuitive scope for the right to self-defense, but she does so at a cost: she is now unable to avail herself of the Moral Obligation Argument that seemed so natural on Locke's account. So by arguing for a unified right to self-defense that applies to both culpable and nonculpable sources of harm, she has foreclosed the usual way - we might loosely call it Locke's way-of establishing the existence of a mandatory legal right to self-defense, namely to infer it from the existence of a moral right to the same.

To see this, consider a now canonical example in the philosophical literature on self-defense, the case of the so-called innocent threat. ${ }^{24}$ The innocent threat is a man who has been pushed off the edge of a cliff and is barreling toward you as you sit on a terrace below. The problem is that he is fat, very fat, and if he lands on you he will kill you. The only thing you have time to do is shift the position of an awning over your head. If you do shift the awning, he will be catapulted into a ravine and die, and you will

${ }^{22}$ See Judith Jarvis Thomson, Self-Defense, 20 PHIL. \& PUB. AFF. 283, 299 (1991) (arguing that self-defense is permissible against "threats" as well as against aggressors).

${ }_{23}$ That is, for Thomson, the underlying right is the right not to be killed, rather than the right to life, as it was for Locke. See id. at 288. Thomson shows convincingly that it is problematic to think of the underlying right involved as a right to life. But it is also problematic to think of it as she does. For one thing, the right must also include the right not to be assaulted, the right not to be raped, etc. We could of course list the many things you are entitled to use force to prevent another person from doing to you and call that the right, or, alternatively, think of the right as divided into a series of smaller self-defensive rights. But it seems less ad hoc to think of the various duties involved as stemming from a single, nondisjunctive right, such as a right to bodily integrity.

It also seems questionable to link the definition of the right to the act by which a person would infringe it. Defining the right this way runs the risk of making the right vacuous: it is a right that another not do $\mathrm{A}$, which places an obligation on $\mathrm{X}$ not to do $\mathrm{A}$, except in the case in which $X$ has a right to do $A$.

${ }^{24}$ See Thomson, supra note 22, at 287. It adapts one of Robert Nozick's examples. See ROBERT NOZICK, ANARCHY, STATE, AND UTOPIA 34-35 (1974). I shall adhere to Thomson's terminology and distinguish "innocent threats" from "innocent aggressors." Sometimes I shall refer to these categories collectively as "innocents," since the difference between them is not important for our purposes. 
survive. If you do not shift the awning, you will die and he will survive, because you will break his fall. Thomson thinks it permissible for you to shift the awning, because the innocent threat will infringe your right not to be killed by him if he lands on you. You may kill him to prevent the infringement of right. ${ }^{25}$ Most philosophers who have considered the example agree that it would be permissible for you to shift the awning, so let us grant this claim.

Now modify the example a bit. Suppose the innocent threat sees you about to shift the awning, and he has just enough time to pull out a gun and shoot the handle of the awning (he is a very good shot). This would disable you from opening the awning. May he do so? Or does your right to shift the handle of the awning impose a duty on him to refrain from interfering with your attempt to shift the awning? I suspect many will think that if it is permissible for you to shift the awning, it is permissible for the innocent threat to protect himself by shooting the handle of the awning. After all, you are now something in the nature of an innocent threat to him, since you threaten to infringe his right not to be killed by you. ${ }^{26}$ And if it is permissible for you to protect yourself by shifting the awning at the same time that it is permissible for him to protect himself by shooting the handle of the awning, the right to self-defense does not impose a duty of noninterference in this case. At least it does not do so with respect to a person whose life is endangered by the exercise of your right to self-defense.

Now perhaps someone will want to reject the claim that it is permissible for the innocent threat to shoot the handle of the awning. For unlike your shifting the awning, his shooting the handle is designed to keep you in place to use you as a cushion to break his fall. You are not seeking to make use of him. You would be happy if he never existed. He, on the other hand, seeks to press your body into service (so to speak) to save himself from dying. Arguably, this is impermissible. Notice, for instance, that if we say it is permissible for the innocent threat to shoot the handle of the awning, we might also have to allow that he could shoot you to prevent you from moving the handle. What if instead of moving the awning, you simply prepare to step out of the falling man's path? May he shoot you to prevent you from

25 See Thomson, supra note 22, at 287-89.

${ }^{26}$ I suggest that you are an innocent threat, rather than an innocent aggressor, since you are not really aggressing against him, even though you are intentionally doing something you know will harm him. But again, nothing in the argument turns on the distinction between innocent threats and aggressors. 
stepping out of his path? Surely not! So why should it be permissible for him to shoot the handle of the awning to prevent you from moving it ? $^{27}$

$I$ think it is probably permissible for the innocent threat to shoot the handle of the awning. But I also think it probably is not permissible for him to shoot you to prevent you either from moving the awning or from stepping aside, and I admit that it may not be easy to reconcile these intuitions. Similarly, if you had a gun and could use it to shoot the gun out of his hand in order to prevent him from shooting the handle of the awning, I think it would be permissible for you to do so. This might be true even if it were not permissible for you to shoot him to prevent him from shooting the handle of the awning. ${ }^{28}$ What could explain these distinctions? One difference between the cases may be helpful: shooting the handle of the awning is an attempt to interfere with your act of self-defense, with the foreseeable but collateral consequence that you will die; shooting you, on the other hand, is a direct attack on you. The duty not to interfere with the self-defensive act of another is possibly less stringent than the duty not to initiate a fresh attack. This would be true if the right to self-defense were a weaker right than the right violated in a direct attack, such as the right to life or the right not to be killed or harmed unjustifiably. ${ }^{29}$ But we are not yet in a position to appeal to the weakness of the right to self-defense to explain the difference between these examples. ${ }^{30}$ For the moment, then, let us simply accept that it

${ }^{27}$ David Gauthier has suggested to me that it would violate the Lockean proviso for the innocent threat to shoot the handle of the awning. The proviso, under Gauthier's interpretation, says that it is permissible for you to save your own life only if you do not "better[] [your] situation through interaction that worsens the situation of another." DAVID GAUTHIER, MORALS BY AGREEMENT 205 (1986). The proviso allows you to shift the awning, because the innocent threat is made no worse off by your interaction with him than he would have been in the event of your nonexistence, and shifting the awning would leave you no better off than you would have been without his existence. He may not shoot the handle of the awning, however, because he would be bettering himself by your existence, given that he would have died had you never existed.

${ }^{28}$ But since it would be permissible for you to shoot the innocent threat in order to prevent him from landing on you, this variation does not have any practical implications.

${ }^{29}$ On the comparative strength of the right to life and the right to self-defense, see Baruch Brody, Thomson on Abortion, 1 PHIL. \& PUB. AFF. 335, 337 (1972), arguing against Thomson on grounds that the right to self-defense of the expecting mother is weaker than the right to life of the fetus), and Susan Levine, The Moral Permissibility of Killing a 'Material Aggressor' in Self-Defense, 45 PHIL. STUD. 71 (1984), arguing that a mother's right to self-defense cannot trump her fetus' right to life. Thomson herself appears to hold the reverse position. See JUdith JARVIS THOMSON, Self-Defense and Rights, in RIGHTS, RESTITUTION, AND RISK 46 (William Parent ed., 1986).

${ }^{30}$ The examples, after all, are part of the argument designed to substantiate the claim that self-defense is a weaker kind of right. Notice that the distinction between shooting the handle and shooting you might take care of the difficulty with this case under Gauthier's proviso. See supra note 27. For the innocent threat is not trying to better himself by your existence, but is simply seeking to avoid being catapulted into a ravine by hitting an awning. Suppose, for ex- 
would be permissible for the innocent threat to shoot the handle of the awning, even if it would not be permissible for him to shoot you.

In general, whenever a person legitimately defends himself against an innocent, namely someone who poses a threat to his life but who is not culpably attacking him, the innocent has a right to defend himself against the self-defensive attack by seeking to interfere with it. What this suggests, at least in the first instance, is that the right one has to defend one's own life against innocents may not be as strong (or not as weak) as the claim-right picture would lead one to think. Not as strong because it does not operate to the exclusion of other conflicting rights. Not as weak because it may operate in the face of such conflicting rights-it is not as easily eliminated as the claim-right picture would suggest. Of particular relevance for the Moral Obligation Argument are the implications for third parties. If the right to self-defense against innocents does not impose a duty of noninterference on one's assailant, perhaps it does not impose duties of noninterference on third parties either. And if this is correct, we cannot infer a duty on the part of the State to extend a legal right to self-defense from the existence of the underlying moral right. In order to preserve the Moral Obligation Argument, then, one would have to show that third parties remain subject to duties of noninterference in the case of a conflict of first party rights. Let us accordingly attend more carefully to the situation of a third party who happens upon the scene as the innocent threat begins to fall.

\section{THIRD PARTIES}

Suppose a third party sizes up the situation accurately: she sees that without interference, the man falling from the cliff will land on you and crush you, but she also sees you about to shift the awning and him about to shoot the handle of the awning. What should the third party do? Or perhaps we should ask: what may the third party do, assuming she is inclined to interfere? The following answer seems in keeping with the claim-right approach. Your right to shift the awning places others under a duty of noninterference. Normally it places all others under a duty of noninterference, but here we must allow an exception. The person falling from the cliff has a right to defend himself against you and exercising that right will require him

ample, he thinks he would have a better chance of surviving hitting a terrace than falling into a ravine. Is he obligated to allow himself to be catapulted into the ravine just because there is a person in his path on the terrace?

Even if this response does not meet the claim of proviso violation, Shelly Kagan has provided reasons to question whether baseline tests such as the proviso are defensible, and thus I am uncertain whether to think of the right to self-defense as limited in the way Gauthier suggests. See SHELly KAGAN, THE LIMITS OF MORALITY 92-101 (1989) (giving counterexamples to baseline tests). 
to interfere with your right to defend yourself against him. A third party, however, is not situated in this way. She has no such right, and thus she cannot escape from the duty under which your right places her. Only the possession of an opposing right could release the third party from the duty not to interfere with your right to self-defense. ${ }^{31}$

Similarly, the innocent threat has a right to shoot the handle of the awning, and this right normally places others under a duty of noninterference. There is an exception, however, in your case, since you are directly threatened by his attempt to shoot the handle and you have a right to defend yourself against the threat to your life. (Recall that you may shoot the gun out of his hand to prevent him from shooting the handle of the awning.) Once again, however, a third party remains subject to the duty not to interfere with the innocent threat's right to shoot the handle of the awning, since she has no opposing right whose assertion would release her from that duty.

Although third parties generally have a moral permission, but not a right, to assist a person acting in his own defense, they also have a duty not to interfere with the valid exercise of such a right. A duty not to interfere is surely stronger than a mere moral permission to interfere. Thus in a case of conflicting rights to self-defense, a third party's permission to assist is outweighed by her duty not to interfere. Moreover, the duty of noninterference the third party has with respect to one side is perfectly compatible with the duty of noninterference she has with respect to the other. If there is no right to interfere on either side, and a duty not to interfere on both sides, the clear course is for the third party not to interfere. That way she can satisfy both of her duties and interfere with no one's right.

Matters would be different if a third party had a duty to assist someone acting in his own defense. For in this case the third party would have a duty

31 There is a debate over whether to think of the duty as overridden in such a case, or whether to think of it as extinguished by a conflicting duty. See, e.g., Ruth Barcan Marcus, Moral Dilemmas and Consistency, 77 J. PHIL. 121, 126 (1980) (defending the former position). The problem with the first solution is that a person has a duty to do $A$, even though he also has a conflicting, and perhaps stronger, duty to do $B$. And it seems strange to say that a person has a duty to do $A$ and a duty to do $B$ when satisfying his duty to do $A$ precludes his satisfying his duty to do $B$. For then we would have to allow both that a person ought to do $A$, and that he ought to do $B$, when he cannot do both at once. If he ought to do $A$, it would seem to follow that he ought not to do $B$. But since he ought to do $B$, it looks as though it is simultaneously true and false that he ought to do $B-$ a contradiction.

Thomson points out, however, that we need not infer that a person ought to do $A$ from the fact that he has a duty to do $A$. He might have a duty to do $A$, even though he ought not to do $A$, given that his duty to do $B$ is stronger than his duty to do $A$. Thomson also argues that if we think of the duty to do $A$ as extinguished by the conflicting duty to do $B$, we will have a difficult time making sense of the "moral residue" that remains from failing to do $A$, such as the duty to apologize or to make amends to the person to whom doing $A$ is owed. See THOMSON, supra note 9 , at 82-87. 
to assist you, say, by shooting the gun out of the hand of the innocent threat, and she would have an incompatible duty to assist him, say, by shooting the handle of the awning. While she might be able to accomplish both of these tasks seriatim (suppose our third party is a really good shot), that would hardly satisfy both duties of assistance, since the end result would be that you would be crushed. Under these circumstances, assisting both parties cannot truly count as assisting you. So if there were an affirmative duty to assist both parties, those duties could not both be satisfied, and the third party would face a dilemma. In this case, it would be permissible for her to draw on other considerations to resolve the conflict, such as that one party is working on a promising cure for cancer, that one party is her child, that one party is a serial killer, or even that one party is congenitally clumsy and keeps endangering people by falling off cliffs. Because there is no general duty to assist persons defending themselves, however, third parties only have a moral permission to assist, and a permission must take a back seat to any duty that might happen to conflict with it.

So far so good for the Moral Obligation Argument. Self-defense is a claim right that places others under a duty of noninterference. A person (say $B$ ) whose right is threatened by the exercise of another's (say $A$ 's) right to self-defense does not have this duty of noninterference. ${ }^{32} B$ may interfere with the exercise of $A$ 's right to self-defense in order to vindicate his ( $B$ 's) right. Where $A$ threatens $B$ 's right to life, ${ }^{33} B$ is exercising a right to selfdefense, a right that places others under a duty of noninterference. But since $A$ is exercising a right with which $B$ is seeking to interfere, $A$ is not subject to this duty. Thus $A$ and $B$ both have a right to self-defense under the circumstances, and the exercise of neither right places the other under a duty of noninterference. By contrast, a third party (say $C$ ) is subject to the duty of noninterference that correlates with both $A$ 's and $B$ 's right to selfdefense. $C$, after all, is not exercising a conflicting right with which these rights interfere. And, barring special circumstances, $C$ has no duty to assist that might release her from her duty not to interfere. $C$ thus has no basis for seeking to interfere with either $A$ 's or $B$ 's right to self-defense. The correct course is for $C$ to stay out of the fray.

As third party to the right of self-defense of its citizens, the State is subject to a duty of noninterference. It looks, then, as though the State must grant its citizens a legal right to self-defense unless it can make a conflicting claim of right. Arguably, the State is not itself a bearer of rights; only the

\footnotetext{
32 At any rate, he does not have a conclusive duty of noninterference.

${ }^{33}$ Or as Thomson would say, the right not to be killed by the person attacking.
} 
citizens that empower it possess such rights. ${ }^{34}$ The State is therefore obligated to extend a legal right of self-defense to its citizens, since failure to do so would constitute an impermissible interference with their moral right to the same.

Now someone might wish to argue that while an ordinary third party normally has a permission, but not a duty, to assist someone defending his life, the State is not an ordinary third party. Unlike a private citizen, after all, a policeman who stood by and did nothing while a group of thugs beat a person to death would be seriously remiss in his obligations. And if the State has a duty to assist, we would have an argument for why it may interfere with the right in cases of conflict: the State may interfere because it has conflicting duties of assistance, and it must avail itself of subsidiary considerations in order to resolve this conflict. But I think the Moral Obligation Argument is safe from this criticism. For even if the State does have a duty to assist in the above sort of case, we cannot infer from this a general duty to assist self-defenders. After all, the State's duty might extend only to persons attacked by those lacking any conflicting claim of right. We would need a separate argument for determining the scope of the State's duty, and we cannot assume a general duty of assistance in supplying such an argument.

But now notice that there do seem to be cases in which a third party may weigh reasons for intervening, even though she has a duty not to intervene. Here is another example discussed by Thomson. ${ }^{35}$ Suppose $A$ is a property owner and $B$ has a sick child. $A$ 's property right places a duty on others not to interfere with $A$ 's use of his property, say, by entering it without $A$ 's permission. But the only route to the hospital $B$ can take if he is to save the life of his child requires him to cross $A$ 's property, and $A$ is not home for $B$ to ask permission. May $B$ cross the property? Surely the answer is "yes." One explanation might be that $B$ has a right to secure medical attention for his child which conflicts with $A$ 's right to keep people off his land. And because the damage to $B$ will be very great if he cannot exercise this right, and the damage to $A$ very slight if he cannot exercise his right to keep people off his land, $B$ 's right ought to prevail over $A$ 's. ${ }^{36}$

${ }^{34}$ One exception to this appears in the international arena, where we think of states as having sovereignty rights against other states. But this is not the sort of right at issue here.

35 See ThOMSON, supra note 9, at 98-100.

${ }^{36}$ Must $B$ 's right always prevail over $A$ 's in virtue of the fact that the former concerns bodily integrity and the latter merely property? For example, what if the damage to $A$ 's property would be very great and the consequences of $B$ 's failing to reach the hospital would be a much lesser harm than the death of his child? Suppose his child would lose an arm. What about a finger? 
Presumably it would still be permissible for $A$ to seek to keep $B$ off his property, for example, by installing a fence around the perimeter. ${ }^{37}$ Suppose that $A$ is busy putting the finishing touches on his fence, and $B$ arrives, sick child in tow. $B$ is trying to find a place to cross the land and $A$ is trying to prevent him from crossing. As we have said, $B$ 's right to cross the land is more stringent than $A$ 's right, even if $A$ may still try to keep $B$ off the land. Would it not be permissible for $C$, then, who is watching the conflict, to intervene on $B$ 's side, by removing a portion of the fence? Indeed, we could say that $C$ ought to help $B$ if he helps anyone, since $B$ has the stronger claim under the circumstances. ${ }^{38}$ This is so even though $C$ is not obligated to help $B$.

Notice, however, that the Moral Obligation Argument implies that $C$ ought not to help $B$. For it looks as though $C$ would violate a duty to $A$ not to interfere with the exercise of a right, namely the right $A$ has to keep people off his land by maintaining a fence around it. Matters would be different if $C$ had a duty to assist $B$, but we are assuming $C$ has no such duty. So if $C$ has no duty to assist on either side, and a duty to refrain from interfering on both sides, once again it looks as though $C$ ought to stay out of the fray. In particular, the fact that $B$ has the stronger of the two claims does not give $C$ license to intervene, since by helping $B$ he would be violating his duty to $A$ not to intervene. The conclusion in this case, however, seems unacceptable. Surely $C$ may intervene on the side of the person with the stronger right. If this is correct, it cannot be true that a third party's moral permission to assist is always weaker than a duty she has not to interfere on one side or the other of a conflict of rights.

The result is striking: the fact that each party to a conflict is acting from a claim of right, in combination with the fact that a third party has a permission, but no right, to intervene, does not entail that a third party may not intervene on one side or the other of such a conflict. Although a third party may have a general duty not to intervene, this duty can be overridden if one of the parties has a stronger entitlement than the other, even if the third party has no duty to further that entitlement. We can conclude that a third party may sometimes choose in accordance with a mere moral permis-

${ }^{37} A$ may not, however, use any means at all to accomplish this end. For example, he may not shoot $B$ to prevent him from crossing the property.

38 On some views, however, $A$ does not have a right to keep $B$ off his land if it is true that $B$ may cross $A$ 's land. Some philosophers have attempted to specify $A$ 's right in such a way that it would exclude the entitlement to keep $B$ off the land. There are a host of difficulties with proceeding this way, however, as Thomson has adequately argued. See THOMSON, supra note 9, at 91-100 (arguing against the "Internal-Condition" and the "External-Condition" Replies); see also Thomson, supra note 29, at 37-42 (arguing against "specification" views of rights, namely accounts that specify the content of rights so as to avoid conflict). 
sion she has to intervene in the face of a duty she has not to intervene. When, we might ask, is this so?

At the very least, a third party may intervene on the side of the person with the stronger entitlement, when that entitlement is the stronger of two rights. ${ }^{39}$ If this is correct, it would appear to follow that the third party in the case of the innocent threat may also take into account the fact that one party is about to discover a cure for cancer, that one party is a serial killer, or even that one party is congenitally clumsy and keeps falling off the edge of cliffs and endangering those below. For these factors are surely relevant to determining the strength of the right each party is exercising in that case. It looks, then, as though a third party observing a conflict of rights is in a similar position to someone weighing conflicting duties of assistance: it is permissible for her to weigh reasons for intervening on one side or the other, and to intervene on the side these reasons suggest. While she may not be entitled to intervene for just any reason, there is some set of reasons that would provide an adequate justification for wading into the fray. This is so even though the third party has no duty to intervene on either side, and even though she has a duty not to intervene if at least one party is exercising a right.

If this is correct, the implications for the Moral Obligation Argument are as follows. The State, in the position of third party to a conflict, may sometimes interfere with the exercise of the right to self-defense. For there are at least some cases in which the moral right does not place the State under a duty of noninterference. Which cases? The foregoing examples suggest that the State may intervene where one person's right to self-defense conflicts with another person's right to self-defense if the State has good reason for favoring one right over the other. ${ }^{40}$ In such cases, the State may weigh the conflicting rights, along with any applicable subsidiary reasons

${ }^{39}$ Must the entitlement always be protected by a right? Suppose, for example, that the parent's claim to cross the land is based on strong consequentialist reasons instead. The parent, say, is a felon, and the child is his co-felon who was injured in an attempt to burglarize $A$ 's house. Nevertheless the child will die if the parent does not reach the hospital soon. Perhaps under these circumstances the parent has no right to cross the land, but perhaps it is still permissible for him to do so, given the comparative magnitude of the two harms involved. May the third party not intervene on the parent's side in this case, based on the importance of saving a child's life? Some philosophers, of course, reject the idea that considerations of utility could ever outweigh rights. But those who accept it must also accept that third parties may sometimes act against a right for reasons of utility.

${ }^{40}$ The reasons for thinking one right stronger than another have a consequentialist flavor. But it is also plausible to think that some of these reasons might themselves be reasons of justice, in particular, reasons of distributive justice. See PHILlIP MONTAGUE, PUNISHMENT AS SOCIETAL-DEFENSE 40-49 (1995) (suggesting an account of self-defense as following from a principle of distributive justice). 
whose consideration is not precluded by the rights in question, in order to resolve the conflict. ${ }^{41}$

We have thus identified one basis for a State's restricting the legal right to self-defense: the State may "regulate" the right to self-defense in any case in which the right conflicts with the right to self-defense of another. Since the right to self-defense is always subject to conflict when exercised against innocents, it looks as though the State may, for good reason, restrict the right to self-defense against innocents. It might, for example, pass a law forbidding self-defense against innocents. Alternatively, it might prohibit an innocent who was attacked from responding to the original attack with force. The question of whether the State has an obligation to recognize the right to self-defense of its citizens is thus crucially transformed in the case of self-defense against innocents, for it now appears to require exploration of the reasons the State has for interfering with the right. The inquiry will thus be a substantive one about the various interests involved instead of an exploration of the State's moral obligations. That is, one answer to the question of whether the State has an obligation to extend a right of selfdefense has been foreclosed, namely that the State must extend such a legal right because the corresponding moral right of its citizens places the State under an obligation to do so. At least where self-defense against innocents is concerned, whether the State has such a duty does not appear to depend on the existence of the underlying moral right. We should conclude that the Moral Obligation Argument fails for at least one class of cases-that involving self-defense against innocents.

\section{THE SHRINKAGE STRATEGY}

Part II argued that the right to defend oneself against innocents does not require third parties to refrain from intervening in a conflict between two rights-holders, and that the State may therefore restrict the right in this context. In this Part, I suggest that this conclusion applies generally to other cases of self-defense. If this is correct, we would have reason to reject the Moral Obligation Argument altogether, because that argument depends on the view of the moral right as imposing duties of noninterference. My claim is not that one is forced to abandon this picture of the right in all cases. Rather, my suggestion is that it is hard to give a plausible account of selfdefense if one insists on seeing the entitlement in this way. In short, I suggest that conceiving of the right as a liberty, rather than as a claim, makes

${ }^{41}$ In addition, for someone who thinks that considerations of utility may sometimes prevail over rights, the State may also interfere with the right to self-defense for reasons of utility. 
better sense of the various characteristics we attribute to the entitlement, even though this is so much the worse for the Moral Obligation Argument.

The argument for this suggestion depends on the plausibility of a certain requirement I shall call the "Unity Condition." This requirement says that an account of self-defense should be unitary across different sources of harm to a potential victim's life. In other words, self-defense against culpable aggressors should be explained in the same way as self-defense against innocents. And since we cannot treat the entitlement as a claim right in all cases, acceptance of the Unity Condition suggests that we regard the right as a liberty right instead. ${ }^{42}$

We now have another way of putting the dilemma the modern theory of self-defense confronts: contemporary philosophical accounts of the moral right to self-defense attempt to accept the Unity Condition at the same time that they adhere to a view of the right as a claim right. That is, they try to include the entitlement to defend against innocents within the scope of the right, but the conception of the right remains the standard one of the right as imposing duties of noninterference on other agents. My suggestion will be that we should abandon the claim-right picture. But before we explore the account of self-defense as a liberty right, let us consider the alternative, namely that we abandon the Unity Condition instead.

Suppose one were willing to accept that the right to defend against innocents has a very different character from the right to defend against culpable aggressors. Not all moral philosophers would find this solution unpalatable, since some already think that the strength of the entitlement to defend oneself with force varies with the culpability of one's assailant. ${ }^{43}$

${ }^{42}$ While the legal right might be unified and the underlying moral right not, it is instructive that no legal system distinguishes the entitlement to defend oneself against culpable aggressors from the entitlement against innocents.

${ }^{43}$ Philosophers often assert the comparative weakness of the right to self-defense against innocents, but they rarely attempt to argue the point. Nancy Davis, for example, insists: "Other things being equal, we are entitled to be more aggressive in repelling a threat that is a clear instance of hostile or malevolent conduct than we are in repelling an innocent threat." Nancy Davis, Abortion and Self-Defense, 13 PHIL. \& PUB. AfF. 175, 183 n.17 (1984). It is curious that Davis takes this position, since she thinks of self-defense as an agent-relative permission, and that view most naturally goes with a picture of the strength of the right to self-defense as dependent on the danger to the self-defender, rather than on the characteristics of the attacker. Michael Otsuka takes the position one step further, arguing that self-defense against innocent threats may actually be morally impermissible. See Michael Otsuka, Killing the Innocent in Self-Defense, 23 PHIL. \& PUB. AFF. 74, 74 (1994) (arguing "that the intentional or foreseeable killing in self-defense of such an innocent person who is not about to die soon anyway is unjustifiable"). A more nuanced way of articulating the distinction appears in Jeff McMahan, Self-Defense and the Problem of the Innocent Attacker, 104 ETHICS 252 (1994). McMahan argues that a more stringent proportionality requirement applies where self-defense is exercised against innocents. See id. at 265-66. 
Making use of this intuition, one might say that what we typically think of as the right to self-defense is in fact a collection of two different things. On the one hand, there is a claim right to defend our lives with force, a right that imposes duties of noninterference on other agents. On the other hand, there is a mere permission, that is, a liberty right, to protect oneself against innocents. The claim right is limited to cases in which the right is immune to conflict, ${ }^{44}$ and the liberty right covers the rest.

This hybrid approach arguably better explains the various features of the above two kinds of cases. For example, even if third parties may intervene with the exercise of the right against innocents, we still need a way of explaining why such intervention would be impermissible against someone defending herself against a culpable aggressor. Or consider the argument that an innocent retains the right to defend herself against someone whose life she is innocently threatening. We still need to be able to explain why a culpable aggressor does not retain this right. We can account for both if the right to self-defense against culpable aggressors remains a right in the claim-right sense, even if we must explain the entitlement differently in other cases.

Someone who took the foregoing approach could still maintain that the State has an obligation to extend a right of self-defense to its citizens in cases involving culpable aggressors; it may, but need not, extend the right to those threatened by innocents. Taking a hybrid approach to the moral right would not foreclose treating the legal right in a unified way. There might still be good reasons, particularly pragmatic ones, for the State to extend the right in the latter cases. But the Moral Obligation Argument would apply only to the exercise of the right in the former cases. Let us call this the "Shrinkage Strategy." 45

Legal theorists, however, reject the intuition. See George P. Fletcher, Proportionality and the Psychotic Aggressor: A Vignette in Comparative Criminal Theory, 8 ISR. L. REV. 367, 379 (1973) ("The focus is not upon the culpability of the aggressor, but rather on the autonomy of the innocent agent.").

${ }^{44}$ Some philosophers explicitly embrace a definition of rights that makes them immune to conflict. See, e.g., HILLEL STEINER, AN ESSAY ON RIGHTS $89-90$ (1994) ("A vested liberty is one surrounded by an impenetrable perimeter."). Steiner thinks we must understand rights in such a way that they are "compossible"-that is, that allows them to coexist without conflict. Id. His view would naturally fit with the "shrunken" view of the right to self-defense I am exploring here.

${ }^{45}$ Some criminal law theorists make another kind of distinction between rightful and merely permissible self-defense: that between actors who are actually defending their lives and those who reasonably, but mistakenly, think they are defending their lives. See GEORGE FLETCHER, RETHINKING CRIMINAL LAW $\S 10.1 .2$ (1978) (discussing treatment of the reasonably mistaken self-defender). While this distinction is a more plausible one than that between defending against culpable aggressors and defending against innocents, I believe there is good reason to reject it as well. See Claire O. Finkelstein, Self-Defense as a Rational Ex- 
The first thing to notice is that the shrinkage required to adopt this strategy would be quite extensive, more extensive than I have indicated thus far. Until now we have focused on "intra-right" conflicts, ${ }^{46}$ namely conflicts where one person's right to self-defense conflicts with another's right to the same. We have seen that the right to self-defense is subject to such conflicts where it is exercised against innocents. The right does not appear to be subject to intra-right conflicts where the right is exercised against culpable aggressors, ${ }^{47}$ since a culpable aggressor does not retain a right to defend himself against someone who is justifiably attacking him. ${ }^{48}$ But the right to self-defense against culpable aggressors is subject to "inter-right" conflicts, namely conflicts with a different kind of right. ${ }^{49}$ The same arguments we used above to show that the State may interfere with the right to selfdefense against innocents applies to cases of inter-right conflict as well. The Shrinkage Strategy would thus have to shrink the right to self-defense all the way down to cases involving culpable aggressors, and only those in which the exercise of the right does not conflict with another's right.

cuse, 57 U. PITT. L. REV. 621, 627-28 (1996) (arguing against the view that accounts for actual and mistaken self-defense differently).

46 JEREMY WALDRON, LiBERAL RIGHTS: COLLECTED PAPERS 1981-1991, at 203-24 (1993) (defining "intra-right" conflicts as "conflicts between different instances of the same right").

Support for this claim appears in the legal literature. Consider, for example, Russell Christopher's argument in favor of the "subjective" view of self-defense, namely the view that a defendant must have been aware of the danger to himself in order to claim self-defense:

(1) On the objective view of self-defense, two agents can both be justified in defending themselves against each other, where both are culpable aggressors.

(2) If an agent has a justification, no one may interfere with his act.

(3) On the subjective view of self-defense, the above sort of conflict cannot arise.

(4) Therefore, the objective view of self-defense must be rejected in favor of the subjective view, on pain of contradiction between (1) and (2).

See Russell L. Christopher, Unknowing Justification and the Logical Necessity of the Dadson Principle in Self-Defense, 15 OXFORD J. LEGAL STUD. 229, 239-45 (1995). If one were to substitute "right" for "justification" in the second premise of Christopher's argument, one would have a caricature of the claim-right picture. But, as we have seen, this premise is false where the right to self-defense is concerned. Assuming Christopher's third premise is correct, however, the claim-right picture of self-defense would hold for the exercise of the right against culpable aggressors, so long as an agent is aware of his entitlement to claim the defense at the time he acts.

${ }^{48}$ It seems plausible to suppose on a claim-right picture that this is because the culpable aggressor forfeits his right to life by initiating a culpable attack, and the right to self-defense must be parasitic on some such right. But the precise reason for this is not important for our purposes.

${ }^{49}$ See WALDRON, supra note 46, at 203-04 (defining "inter-right" conflicts as conflicts between two different rights). 
Consider another of the canonical examples in the philosophical literature on self-defense, the case of the innocent shield. ${ }^{50}$ You spy a tank coming towards you, the person in it apparently trying to kill you. Fortunately, you have an anti-tank gun you could use to blow up the tank. As you are about to fire, you notice a baby strapped to the front of the tank, which your aggressor has placed there to use as a kind of "shield" against your counterattack. May you attempt to save your life by blowing up the tank? The philosophers who have considered this example all appear to agree that it is permissible for you to blow up the tank, baby and all. ${ }^{51}$ I think, moreover, that they are correct. ${ }^{52}$ Allowing a culpable attacker to arrange matters so that it is morally impermissible for his intended victims to defend themselves against his attack seems to place an unfair burden on potential selfdefenders. ${ }^{53}$ I see no reason why a person under attack should be obligated to forego an otherwise permissible act of self-defense in order to avoid killing an uninvolved bystander who happens to be in the way. Let us assume, then, that it is permissible for you to blow up the tank.

${ }^{50}$ This example was introduced by Robert Nozick as well. See NoZICK, supra note 24, at 35 (discussing "innocent shields of threat"). It has been famously elaborated by Thomson. See THOMSON, supra note 9, at 370-71.

51 See, e.g., THOMSON, supra note 9 , at 370 . As Thomson points out, it surely would have been permissible for the Belgians to defend themselves against the Germans if the latter had placed a baby on the front of each of their tanks. See id.

52 Note that Gauthier's proviso appears to allow it. See supra note 27 (explaining Gauthier's proviso test). The proviso suggests that you may blow up the tank because you are not bettering your own situation by making use of its existence (although your existence is certainly lowering its baseline, since it is worse off with your existence than without it). In the absence of the baby, you would blow up the tank and live, and thus you may proceed, because killing the baby leaves you no better off than you would have been without its existence.

${ }^{53}$ American criminal law is as insistent in its condemnation of self-defense under these circumstances as the moral philosophers are in condoning it. The Model Penal Code ("MPC"), for example, suggests that a person loses the right to self-defense if he "recklessly or negligently injures or creates a risk of injury to innocent persons." MODEL PENAL CODE $\S 3.09(3)$ (1962). But the criminal law is not consistent in protecting the lives of innocent bystanders. For example, duress is sometimes allowed as a defense to murder. See, e.g., MODEL PENAL CODE $§ 2.09$. My own view is that the MPC's approach to duress is correct on this point, and that the treatment of self-defense should follow suit. See Claire O. Finkelstein, Duress: A Philosophical Account of the Defense in Law, 37 ARIZ. L. REV. 256 (1995).

It is also important to stress that the law's position need not reflect an intuition that selfdefense would be morally impermissible where it would threaten the life of a bystander. It may be that although it is morally permissible for you to blow up the tank, there are good grounds for making it illegal for you to do so nonetheless. But I suspect that the law's approach is not justified on pragmatic grounds either, for the reason suggested above: disallowing self-defense under these circumstances provides incentive for an attacker to surround himself with innocent bystanders before launching his attack. The law's sweeping condemnation of self-defense where the lives of bystanders are at issue thus strikes me as neither morally nor pragmatically required. 
Now consider a variation in which a third party enters the scene just as you are about to open fire. The third party also has a gun, which she could use to protect the baby by shooting the anti-tank gun out of your hand. If she does so, however, the occupant of the tank would immediately open fire on you. Is it permissible for the third party to protect the baby in this way? The first question to ask is whether it would be permissible for the baby to defend himself this way if he had the ability to do so. ${ }^{54}$ For if it is permissible for the baby to defend himself, it might still be impermissible for the third party to intervene, because she might not have as great a privilege to oppose a legitimate act of self-defense as the innocent shield himself. But if it is impermissible for the baby to defend himself, then it must also be impermissible for others to intervene on his behalf. ${ }^{55}$ So let us now imagine that the person strapped to the front of the tank is not a baby, but an adult armed with a gun. May he shoot the gun out of your hand to prevent you from blowing up the tank, knowing that this will result in your imminent destruction? I think he may. ${ }^{56}$ In particular, I think that no one who believes that you may save your life by blowing up the tank should deny the innocent shield the right to save his life in this way. After all, initially he is neither aggressing against you nor threatening your life. You, on the other hand, are aggressing against him. His claim against you should thus be at least as strong as your claim against him.

${ }^{54}$ Most criminal law theorists think that a legitimate right to self-defense entails a right to third-party assistance. See FLETCHER, supra note 45, at $\S 10.5 .2$ (stating that "[a] theory of justified defense . . . generates a universal right of intervention coextensive with the defender's own privilege"); 2 PAUL H. ROBINSON, CRIMINAL LAW DEFENSES $§ 121$ (d) (1984) ("Where conduct is justified, assisting the conduct is similarly justified . . .."). Thus they would probably say that it is sufficient to demonstrate the permissibility of third party intervention in this case to show that the bystander may defend himself. Given that they also think that two acts cannot both be justified and yet conflict with one another, it would be necessary in this case for them to think that you may not blow up the tank with an innocent shield attached to the front. For if this were permissible, the shield could not permissibly defend himself, and this is surely unacceptable.

Some philosophers, however, may be more attuned to the difficulties with third-party intervention. See McMahan, supra note 43, at 266.

55 Here I am assuming that the third party and the bystander have access to the same information. A third party would be entitled to defend a first party in a situation in which the first party could not defend himself, as long as the third party were aware of the danger to the first party but the first party were not himself aware.

56 Notice that the Lockean proviso seems to allow the innocent shield to defend himself in this way. He does not benefit from your existence, since without you and your anti-tank gun, he would live. Shooting the gun out of your hand would only bring him back to where he would have been in your absence. He is not attempting to better himself by lowering your baseline, even though he is lowering your baseline. Moreover, the proviso in this case even seems to allow the innocent shield to shoot you. 
Now we can apply our earlier arguments to move from the suggestion that it is permissible for the innocent shield to defend himself against you, to the suggestion that it is permissible for the third party to defend the innocent shield in this same way. As we saw before, we can say that the third party may have a perfectly adequate justification for favoring the person strapped to the front of the tank over you, namely that the innocent shield's claim is stronger than yours, since it is his right to life at stake as against your right to self-defense. ${ }^{57}$ Once again, all else being equal, the right to life is arguably stronger than the right to self-defense. Thus, it is permissible for the third party to interfere with your right to blow up the tank.

To adopt the Shrinkage Strategy, it would be necessary to shrink the right to self-defense down to the exercise of the right against culpable aggressors, excluding those cases in which the exercise of the right would threaten an innocent bystander. While the shrinkage may seem extensive, once again it might be defended by pointing out that it makes sense of various intuitions we have about the right. It would explain, for example, why the innocent shield may oppose your efforts to defend yourself, why a third party may rise to the defense of the innocent shield, why the innocent aggressor or threat retains the right to defend himself against you, and also why a third party may sometimes intervene on his side rather than on yours. Should we adopt the Shrinkage Strategy in this form, thus rescuing at least a portion of the Moral Obligation Argument?

There are three sorts of considerations that militate against the adoption of the Shrinkage Strategy, and although none is conclusive, together they make a persuasive case. First, consider the fact that even if defensible, the Shrinkage Strategy would not necessarily solve our difficulties. For we would still be left without an account of the State's obligation to extend the legal right in a large number of cases in which we think the State ought to recognize such a right. Although there may be disagreement about the correct scope of the legal right, there would probably be broad agreement that the State ought to grant a broader right than the one the shrunken picture would, by itself, suggest. The question is how the proponent of shrinkage would explain why the State ought to grant the legal right in those cases in which the moral right does not compel it. One solution is to explain the additional cases in terms of pragmatic reasons for extending the legal right in those cases. But this seems to concede the problem the Moral Obligation Argument was invoked to dispel: the suggestion that the moral right to self-

${ }^{57}$ Granted, it is your right to life that is threatened by the culpable aggressor in the tank, and thus in some sense it is your right to life that is at stake. But the third party is not contemplating siding with the culpable aggressor, and thus he is not contributing to the threat to your right to life, but rather threatening your right to self-defense. 
defense is largely unimportant for the legal right. Thus, the Shrinkage Strategy seems costly to the effort to show that the State is obligated to extend a right of self-defense to its citizens.

A second reason to reject the Shrinkage Strategy is epistemic and can be briefly stated. In many cases it will not be possible to know whether one's attacker is culpable or innocent. While infancy is likely to be discernible, insanity, mistake and other moral excuses are not. Is it plausible to think that whether a person has a moral right to defend her life turns on facts to which she does not have access? Of course it would be difficult to administer a rule that barred self-defense specifically against innocents, and this provides a reason for adopting a unified treatment of the legal right. But this is not an adequate answer to the problem we are now considering, namely whether it makes sense to predicate the moral right on factors of which agents who must invoke the right are normally unaware. Without elaborating further, it strikes me that it does not. ${ }^{58}$

A third objection goes to the heart of the intuition in favor of the Unity Condition. The right to self-defense protects an underlying interest, such as an interest in bodily security. It accordingly seems odd to think that the strength of the right varies with the characteristics of the attacker, rather than with the magnitude of the threat to the relevant interest. After all, my interest in protecting myself against a lethal attack by an enemy is as strong as my interest in protecting myself against a child, or even, for that matter, a bear. It seems no more plausible to say that the strength of my entitlement varies with the source of the threat than it would be to say that the strength of my interest varies with the source of the threat. It is a curious proposition that I have a strong entitlement to defend myself against a culpable attacker because he is culpable, that I have a weaker or perhaps no entitlement to defend myself against a child because she is innocent, and that I may defend myself against a bear not because it is threatening my life, but because it is only a bear. Suppose it is generally morally impermissible to kill bears. Should this weaken my entitlement to defend myself against them? Moreover, if the right attached to characteristics of the attacker rather than to the interest of the victim under threat, a person who reasonably, but mistakenly, used force in self-defense would presumably have no right to self-defense at all. $^{59}$

58 In this regard, I side with those who take a "will theory" approach to rights. See H.L.A. HART, ESSAYS ON BENTHAM 183-85 (1982) (describing a right-holder's control over the assertion of the right as essential to a correct understanding of rights). I do not think this incompatible with the view that rights protect interests, which I endorse in the following paragraph.

59 Some criminal law theorists, however, accept this conclusion, because they think that a mistaken self-defender is not exercising a true right of self-defense. See supra note 45 (dis- 
Recall that Locke's account of self-defense ties the right to the moral status of the attacker, and that this makes it difficult to account for the availability of the right against innocents. But notice that the difficulty recedes if one focuses on the threat to the interests of the victim, rather than on the characteristics of the attacker. For there would now be no need to distinguish self-defense against culpable aggressors from self-defense against innocents. In either case, self-defense is permissible because it is necessary to defend interests that can legitimately be defended at the expense of another's life or bodily integrity.

Focusing on the interest defended, however, re-opens several difficulties that were nicely resolved by the Shrinkage Strategy. First, how do we explain why a culpable aggressor does not have the right to defend himself against another's self-defensive response to his attack if it is not because the culpable nature of the attack places the aggressor under a duty of noninterference? Moreover, how do we explain why a third party may only intervene on the self-defender's side when the latter is exercising the right against a culpable attacker? The Shrinkage Strategy may be inelegant, but it at least provides a way of accounting for certain features of the moral entitlement that we presumably would not like to relinquish.

It turns out, however, that it is not necessary to regard self-defense as a claim right to explain these features. The fact that the culpable aggressor may not defend himself against his victim's act of self-defense is easy to explain on a liberty-right picture: the aggressor has no need to defend himself against the victim's counter-attack, for the aggressor only has to desist from his own wrongful attack and the danger to himself goes away. An act of self-defense cannot be permissible if unnecessary to save oneself from harm. The problem of third parties on a liberty-right picture is now easily resolved: the reason a third party may not intervene to help a culpable attacker, but may intervene to help a self-defender, is that the act he assists in the first case is morally impermissible, whereas the act he assists in the second is permissible. Knowingly furthering an impermissible act of another agent without justification is itself impermissible. We need not, then, make use of duties of noninterference to explain the standard features of selfdefense against culpable aggressors.

Let us stop and summarize where we are. A proponent of the claimright picture of self-defense will find herself in the position Locke was in when Thomson attempted to remedy the difficulties with his account: she can only offer a plausible account of self-defense as a claim right where the but mistakenly, acts in self-defense). This is the criminal law theorist's version of "shrinkage." 
right is exercised against culpable aggressors, and not even in all cases of this sort. She will be left without an account of the many other instances in which we normally recognize a legal right to self-defense. Although the modern version of the right has improved on Locke's account by rejecting shrinkage and including the exercise of the right against innocents, the expansive scope of the right leaves the account without a way of explaining the relevance of the moral for the legal right. In particular, it has made it difficult to defend the Moral Obligation Argument, which we said provided the most plausible account of that relevance against the background of other basic liberal assumptions. While expanding the scope of the right was necessary to make the account of self-defense more plausible, the additional plausibility has been purchased at a cost: now we cannot make the right stronger than a liberty right, and this means that the existence of the moral entitlement does not by itself suggest an obligation on the part of the State to equip its citizens with a legal right to the same.

\section{SELF-DEFENSE AS A LIBERTY RIGHT: THE PRE-LOCKEAN ACCOUNT}

Since Locke's introduction of the claim-right picture of self-defense, philosophers have largely ignored the question of whether the State is obligated to respect the moral entitlement to defend one's life with force. Philosophers before Locke, however, were well aware of the difficulty of moving from moral to political entitlements and of the difficulty of making this move for the right to self-defense in particular. It appears, then, that the question of the relation between the moral and the legal entitlement went underground on the modern conception of the right. On my story, we would have an explanation for this rather dramatic shift in emphasis: the Lockean picture suggests that an obligation on the State's part to recognize the right follows trivially from the existence of the right, whereas on the pre-modern picture of the entitlement, accounting for the move from the moral to the legal right is anything but trivial.

In this Part, I wish to consider two pre-modern accounts of the legal right to self-defense, each of which conceives of the moral entitlement as a mere moral permission that falls short of a claim right. Not surprisingly, Hobbes and Aquinas both devote considerable energy to answering the question why a moral entitlement to defend one's life with force should be thought of as giving rise to a legal entitlement to the same. Both seek to account for the move from the moral to the legal right indirectly: the fact that citizens are morally entitled to defend their lives ultimately implies that it is impermissible for the State to forbid them from doing so. But this is not because the existence of the right places the State under a moral obligation of 
noninterference. Rather, the underlying moral permission means that the State would act impermissibly were it to punish citizens for defending their lives. Thus the moral permission, in combination with a theory of political legitimacy, supplies a limitation on legitimate punishment from which the obligatory legal entitlement in question can be derived.

Let us turn to Hobbes's account first, since his view is the closer of the two to the Lockean picture we have been considering. A common criticism of Hobbes is that he is confused about the nature of rights because he conceives of rights as liberties rather than as claims. ${ }^{60}$ The critique is understandable given the difference between the modern and the pre-modern pictures of moral rights. But Hobbes's account may hold greater attraction than this criticism would suggest, for the supposedly "confused" conception avoids many of the difficulties the Lockean account encounters.

For Hobbes, the right to self-defense is just a part of the right to act as one's preservation requires, the original and central right man has in the state of nature. This original right is "the liberty each man hath to use his own power, as he will himself, for the preservation of his own nature." ${ }^{, 61} \mathrm{~A}$ right to self-defense in civil society is explained by the fact that there are "some rights which no man can be understood by any words or other signs to have abandoned or transferred," chief among them "the right of resisting them that assault him by force." ${ }^{, 2}$ The reason, Hobbes explains, is that an abandonment of right is a voluntary act, and all voluntary acts aim at some good for the agent who performs them. ${ }^{63}$ Hobbes thinks it can never be to an agent's benefit to abandon his right to self-defense, and thus no man should be understood as having done so voluntarily. Hobbes's argument is somewhat puzzling on this point, since it is easy to think of cases in which it would be to someone's benefit to give up his right to self-defense. But I shall defer exploration of the interesting problems this claim raises to another occasion. ${ }^{64}$

${ }^{60}$ See LEO STRAUSS, NATURAL RIGHT AND HISTORY 197 (1953) (arguing against Hobbes on the grounds that he allows the rights of government to conflict with the rights of individuals); H.L.A. Hart, Are There Any Natural Rights?, 64 PHIL. REV. 175, 179 (1955) (noting that the Hobbesian conception of a moral right is erroneous insofar as Hobbes thought that there is no sense in which a right correlates with a duty or obligation).

61 ThOMAS HobBes, LeViathan ch. XIV, ๆ 1 (Edwin Curley ed., Hackett Publ'g Co. 1994) (1668).

62 Id. $ๆ 8$.

${ }^{63}$ See id. (noting that the object of voluntary acts is a benefit for oneself).

${ }^{64}$ I take up this difficulty with Hobbes's account elsewhere. See Claire O. Finkelstein, $A$ Puzzle About Hobbes on Self-Defense (unpublished manuscript, on file with author) (showing that Hobbes's claim that it could never be rational to abandon the right to self-defense conflicts with Hobbes's overall approach to rationality). 
That Hobbes holds a liberty-right picture of self-defense is apparent from the fact that he thinks a citizen's right to self defense does not place limitations on the sovereign's entitlements. The sovereign has the rights that all persons have in a state of nature, and those rights are unlimited. The natural rights of citizens and the rights of the sovereign can therefore conflict with one another, a point Hobbes repeatedly emphasizes: "If the sovereign command a man (though justly condemned) to kill, wound, or maim himself, or not to resist those that assault him ... yet hath that man liberty to disobey." 65 And, as Hobbes also makes clear, "nothing the sovereign representative can do to a subject... can properly be called injustice, or injury, $" 66$ even commanding a man to wound or maim himself. Like your right to shift the awning and the innocent threat's right to shoot the handle of the awning, or your right to blow up the tank and the innocent shield's right to prevent you from doing so by shooting the gun out of your hand, the right each citizen retains to act in his own defense can exist in the face of a contrary right on the part of the sovereign to impede the exercise of right. On the face of it, then, Hobbes thinks the State is under no obligation to extend a right of self-defense to its citizens.

But is the liberty to defend oneself with force really as weak on Hobbes's account as the foregoing would suggest? Let us first ask whether the fact that the sovereign is under no obligation to extend a right of selfdefense means that he may punish a person for acting in his own defense. There is reason to think Hobbes would say he may not, for Hobbes says that a person who violates a law for the sake of saving his own life is "totally excused," by which he seems to mean totally excused in law, not just in morals. At the same time, however, it seems hard to believe that Hobbes could truly mean that the sovereign may not punish the transgression of law in this case, given that Hobbes thinks the sovereign could do citizens no injustice in doing so. Could Hobbes be suggesting a limitation on the otherwise unlimited rights of the sovereign that does not itself stem from the rights of citizens?

While Hobbes does not address the question directly, we can perhaps extract an answer from his treatment of punishing the innocent. In Chapter XXVIII of Leviathan, Hobbes says that a sovereign who punished the innocent would violate several of the laws of nature. ${ }^{67}$ Among others, he would violate the law of equity, by which he, his judges, and his magistrates are

${ }^{65}$ HoBbES, supra note 61, ch. XXI, ๆ 12.

${ }^{66}$ Id. ch. XXI, 97.

${ }^{67}$ Punishment of the innocent would violate three laws of nature: first, the law requiring men always to look for some future good; second, the law against ingratitude; and third, the law of equity. See id. ch. XXVIII, ๆ 22. 
bound. Our concern is with a different case, since in the face of a law forbidding self-defense, a person who killed in self-defense would not be innocent. (By "innocent," Hobbes seems to mean someone who did not violate the civil law.) Nevertheless, Hobbes does appear to treat the passage and enforcement of laws abridging those natural rights citizens retain in civil society as itself a violation of the laws of nature. This raises the difficult question of what it means for the sovereign to be bound by the laws of nature, a question to which I cannot do justice here. One point, however, can be made without further investigation-that the laws of nature bind in foro interno. Laws that bind only in foro interno are binding before God, but not before one's fellow man. From this we can conclude that although the sovereign is under no obligation to his citizens to pass a law extending a right of self-defense, he would presumably be answerable to God to do so, or at least to refrain from punishing someone who exercised a natural right to self-defense. As Hobbes says, "[H]e who has the Supreme power . . can do no injury to his citizens, even though, by iniquity, he can be injurious to God.",68

This, then, seems to be Hobbes's solution to the question of how the moral right to self-defense obligates the State to furnish citizens with a corresponding civil right: the sovereign sins against God if he does not respect the moral rights of his citizens, because the duty he has in foro interno to respect the laws of nature commits him to protect those rights they do not transfer away in the original Covenant. Although a law that failed to respect the retained natural rights of citizens could be enforced against them without injustice, citizens would have reason to regard themselves as released from any duty to obey such a law. For they could not rationally authorize the sovereign to legislate against the natural law that promotes their wellbeing. Nor could they authorize him to sin against God. In this way Hobbes traces an indirect route from the liberty right to self-defense to a mandatory legal right to the same.

Saint Thomas Aquinas traces a similar path from the moral to the legal entitlement, and he too conceives of the former as more in the nature of a permission than a right in the modern sense. For Aquinas, unlike for Hobbes, there is a fundamental difficulty accounting for the moral permissibility of self-defense. This stems from the existence of a prohibition on killing other human beings, a prohibition that is "absolute," meaning that it cannot be overridden by considerations of the greater good. That is, Aquinas does not accept the idea that a morally prohibited act can be rendered permissible

${ }^{68}$ Id. ch. XXI, ๆ 7 n. 10 (emphasis added). 
by overriding moral considerations. ${ }^{69}$ Let us express this idea by saying that Aquinas does not accept the "logic of override."

Aquinas begins his discussion of the prohibition on killing in the First Article of Question 64 of the Summa Theologica, where he considers whether it is unlawful to kill plants and animals. There he suggests that the prohibition does not apply to these cases, since plants and animals exist for the sake of sustaining human life, and that " $[t]$ here is no sin in using a thing for the purpose for which it is. $" 70$ The logic of override is unnecessary in this case, since the prohibition applies only to human life.

Aquinas does, however, allow for the logic of override in at least one place: the killing of a human sinner is permissible, despite the prohibition on killing humans, if done for the sake of the common good by one authorized to make determinations about that good. A private citizen, however, cannot avail himself of this justification, and even a person authorized to act for the public good cannot avail himself of it to justify killing non-sinners. In this light, self-defensive killing poses a particular difficulty, because it falls within the reach of the prohibition, yet the logic of override does not apply to it. Even if Aquinas did not impose the restriction on private killings he does, many acts of self-defense would still be impermissible, since they involve the killing of non-sinners. This is the problem Aquinas's famous Seventh Article is designed to address.

Aquinas's solution to this difficulty is to say that although killing in self-defense violates the general prohibition against killing, an act that aims at self-preservation is not unlawful, provided the means adopted are proportionate to that end. For, as he says, "[I]t is natural [and therefore lawful] to everything to keep itself in being, as far as possible." ${ }^{, 71}$ While the act by which one attempts to save one's life is also the act by which one kills one's assailant, the latter is an incidental byproduct of a lawful act, for the reason that it is "beside the intention," as Aquinas says. ${ }^{72}$ Since acts take their moral quality from what is intended, the act of self-defense is permissible, even though it would not be permissible to slay one's aggressor if one set out to do so.

What about nonlethal acts of self-defense? Since there is nothing that corresponds to the absolute prohibition against killing when it comes to nonlethal violence, it would be reasonable to think that killing in self-

${ }^{69}$ This should be understood to mean that Aquinas accepts the Pauline principle that one may not do evil so that good may occur.

703 ST. ThOMAS AQUINAS, SUMMA THEOlogica question 64, art. 1, at 1460 (Timothy McDermott ed., Christian Classics 1997).

${ }^{71}$ Id. question 64, art. 7, at 1465.

${ }^{72} \mathrm{Id}$. 
defense is a special case for Aquinas. Aquinas does not deal directly with this question. He does suggest, however, that ordinarily it is not permissible to maim a person, since the members exist for the sake of the body, and the natural purposes of the body require their continued healthy existence. But, where the good of the body requires the removal or destruction of a limb, it is permissible to choose the good of the whole over the good of a single member by one authorized to make that decision. This is why a doctor does not $\sin$ in performing a necessary amputation, for an otherwise impermissible act is rendered permissible if performed by one authorized to judge what the welfare of the whole requires. Similarly, the State does not sin when it cuts off the hand of a robber; it may do so when, and to the extent that, doing so is necessary for the good of the community. In both cases, we have the logic of override: It is permissible to inflict a harm it would otherwise be impermissible to inflict if done for the sake of the greater entity whose good is the object of the lesser. And although Aquinas does not discuss other acts of violence, there is reason to think the analysis would be the same for even minor uses of defensive force. ${ }^{73}$

We are now in a position to consider Aquinas's answer to the question that has been the focus of our inquiry, namely whether the State has an obligation to extend a legal right of self-defense to its citizens. As we have seen, Aquinas does not recognize a natural entitlement on the part of private individuals to kill other human beings in self-defense. One might think, then, that it is perfectly permissible for the State to protect the aggressor if it wishes, since his victim has no right to kill him. But there are restrictions on what the State may do to its subjects by way of punishment. For example, it is never permissible to kill (or harm) the innocent-recall that the logic of override based on community welfare applies only to killing sinners. ${ }^{74}$ Arguably, then, the State would $\sin$ were it to put to death a person who had killed another in self-defense. What about lesser punishment, however, such as imprisonment? Could the State punish a person for acting in his own defense, say, by locking him up for an extended period of time?

${ }^{73}$ Consider, for example, Aquinas's remarks about the rights of parents or masters to discipline their children or slaves with physical force. There Aquinas suggests the need for the sort of reasoning that we otherwise find only in the case of the power of the statesman over citizens of the state. As he says:

[I]t is not lawful for a man to strike another, unless he have some power over the one whom he strikes. And since the child is subject to the power of the parent, and the slave to the power of his master, a parent can lawfully strike his child, and a master his slave that instruction may be enforced by correction.

Id. question 65 , art. 3 , at 1468 .

${ }^{74}$ See id. question 64, art. 6, at 1464-65 (noting that "it is in no way lawful to slay the innocent"). Thus, even if the good of the community required killing an innocent, it would not be open to a ruler to do so. 
From our discussion of maiming, it would appear not. For although the prohibition on lesser harms could be overridden if the good of the community required it, an innocent self-defender is not like a gangrenous limbharming him could not be necessary for the good of the community, since he is a "healthy member" and thus contributes to its good. In this way, we can once again derive an obligation on the part of the State to extend a legal right to self-defense. The source of the legal right is the limitation on the State's legitimate authority, stemming from the sorts and sources of justificatory override to which State actors have access. ${ }^{75}$

Both Hobbes and Aquinas thus think the obligation on the part of the State to extend a right of self-defense to its citizens stems from an independent limitation on what the State, bound as it is to God, may legitimately do. They then derive the necessity of a legal right to self-defense from this limitation on State authority: citizens must be thought of as having a right to do that which the State has no right to stop them from doing. Both authors in effect make the Moral Obligation Argument run in reverse: they argue from limitations on State authority to the existence of a legal right to self-defense. The limitation on State authority, in turn, is based on the existence of a moral permission, rather than a right, on the part of citizens to engage in self-defensive acts. Unfortunately, however, secular political philosophy cannot make great use of either solution, since the relevant limiting principle on State authority is the idea that sovereigns have duties to God. The question, then, is whether we might take instruction from the structure of these two accounts, at the same time that we attempt to discover a secular basis for the limitation on state authority instead.

${ }^{75}$ But the following difficulty arises: is it not also natural, and hence lawful, for a sinner to seek his own preservation? And if a condemned man, for example, may seek his own preservation, would not the State's justification for taking his life not evaporate as soon as the man undertook to defend himself against the State's attack? Aquinas recognizes the problem, and directly addresses it in the Fourth Article of Question 69, where he asks whether a man condemned to death may lawfully defend himself if he has the ability to do so. His negative answer to this question is explained by the fact that if a man is justly condemned, "it is lawful for the judge to combat his resistance by force, so that on his part the fight is unjust, and consequently without any doubt he sins." Id. question 69 , art. 4, at 1486 . This may not seem like much of an explanation, but it is in fact the assertion of a duty correlative with the right of the judge to punish, a duty on the part of the condemned man of noninterference. Aquinas thinks it is sufficient that the judge is justified in putting the sinner to death to show that the sinner is not in turn justified in defending himself. Unlike Hobbes, then, Aquinas does not think it possible for one person to be justified in doing something and for another to be justified in resisting him. Putting matters somewhat anachronistically, we might say that Aquinas retains the idea of rights, where they apply, as correlative with duties. But he does not think of the permissibility of self-defense as a matter of right. 


\section{SELF-DEFENSE AS A LIBERTY RIGHT: A MODERN ACCOUNT}

As we have seen, the problem of whether the State has an obligation to extend a right of self-defense to its citizens arises quite urgently on the picture of self-defense as a liberty right. The entitlement one has to act in one's own defense, on this view, is merely the expression of a permissible preference for one's own life over the lives of others. A mere permission does not compel anyone, least of all the State, to respect conduct in its exercise. If the recognition of a right to self-defense were ever to be thought mandatory on this view, it would have to be because the permissible interest a person takes in her own welfare constitutes a normative constraint on the political entity of which such a person is a member. The problem we must address, then, is how a moral permission to do something can ever justify a person in claiming an entitlement to do the same in civil society.

In this light, the question of the State's obligation to establish a legal right to self-defense has a quite different shape from the modern philosophical understanding of that problem. The question now takes on the form of a standard problem in legal theory: when is it legitimate for the State to outlaw conduct that is not otherwise impermissible? It is not morally impermissible, for example, to drive on the left rather than on the right (assuming there are no prelegal coordination practices already in place), or to fail to file a tax return, or to fail to comply with any number of other restrictions, unless and until the State makes it impermissible to do these things. ${ }^{76}$ The question, then, is whether self-defense is one more morally unobjectionable practice the State is entitled to restrict, or even outlaw, if State interests would be advanced by doing so. May the State outlaw self-defense, the way it may outlaw driving on the left?

We are accustomed to being able to say that whether the State may or may not outlaw morally permissible conduct depends on whether the conduct is the sort to which the agent has a right. By asserting the existence of a moral right to self-defense, we thus suggest the existence of a significant gap between coordination-based rules like traffic laws and laws establishing a right to self-defense. On a liberty-right picture, by contrast, the interest an agent takes in her own life would be something to weigh alongside other legitimate interests. Individuals have, as philosophers sometimes say, an "agent-relative reason" to prefer saving their own lives over the life of an-

${ }^{76}$ Once illegal, it may become immoral to violate the norm. It becomes immoral, that is, only if there is a moral duty to obey the law. This is not the sort of moral impermissibility at issue, however. 
other. $^{77}$ If the State has an obligation to extend a legal right of self-defense, it is because its citizens have a liberty to act on the basis of such reasons that the State may not frivolously invade.

We might begin by asking, then, what reasons the State might have for restricting the liberty of its citizens to defend their own lives. The first reason is suggested by our previous discussion: the exercise of one liberty may make the exercise of another more difficult, and thus the State may decide to restrict some liberties in order to allow for the fuller exercise of others. The second, and perhaps most common, reason for restricting a liberty is that the liberty may conflict with a claim right. $^{78}$ A claim right should dominate a liberty right with which it conflicts. A third reason the State might want to restrict a liberty is that doing so may make society better off as a whole. As Hobbes recognized, the benefits of cooperation cannot be gained if people have an unfettered liberty to act on their morally permissible preferences. $^{79}$

We have already considered instances in which the first and second types of reasons provide a basis for limiting the right to self-defense. As we saw in the cases of the innocent threat and the innocent shield, one person's liberty to defend herself might conflict with the liberty of another to do the same. I have suggested that in such cases, the State may have good grounds for choosing one person's liberty right over the other's. More compelling still are cases in which the liberty to defend oneself conflicts with a claim right. For example, suppose human beings have a right to life. ${ }^{80}$ I have suggested that this right might be stronger than the right to self-defense and that therefore the State may limit the entitlement to defend oneself with force when it conflicts with the right to life of a bystander. But we have not yet explored how reasons of the third type would interact with the liberty to defend oneself.

It would be natural to suppose that self-defensive entitlements would normally conflict with considerations of collective welfare. Welfare considerations would thus provide a basis for restricting the legal right to self-

77 The expression "agent-relative reasons" was introduced by Derek Parfit. DEREK PARFIT, REASONS AND PERSONS 143 (1984) (defining agent-relative reasons as "reasons only for the agent," meaning reasons that are tied to a particular point of view).

${ }^{78}$ We need not answer the question of whether there are any natural rights of this sort, for such a right need not be a natural one.

79 Invoking Hobbes's point in this context may be somewhat misleading, for Hobbes thought that any action would be morally permissible in a state of nature, whereas we are not presupposing such a broad view of moral permissibility. It is thus less obvious for us than it was for Hobbes that moral liberties must be restricted for the sake of cooperative social gains.

${ }^{80}$ I suggest this for purposes of example only. I remain agnostic on whether human beings do have a right to life, and if they do, whether it has the features that claim rights do. 
defense. From this perspective, the liberty-right picture of self-defense may seem problematic, for a liberty right will not resist considerations of collective welfare in the way that a claim right would. A mere liberty to defend oneself is not a "trump" in the way that some think of claim rights. ${ }^{81}$

The liberty to defend one's life with force, however, need not be a general Hobbesian entitlement to do whatever is conducive to one's preservation. Individuals need not have a liberty to do everything the State does not forbid them from doing. And when the liberty of self-defense is conceived as a limited entitlement, the following general claim becomes plausible: considerations of collective welfare support, rather than conflict with, allowing individuals to act in their own defense. The reason for this is that allowing citizens to defend their lives with force is itself of value to the common good. This is, of course, not the value of an act of self-defense to the individual actor of saving her own life. For an individual's reason for preferring her own life to the lives of others is not an objective assertion of the value of such an act. Nor is it the value of people acting in their own defense. For the value of allowing people to act in their own defense is likely to be different from the value of their so acting. The value of selfdefensive acts must be a part of assessing the value of allowing people to act in their own defense. It would, for example, contribute to the value of allowing people to act in self-defense if acting in this way were valuable. But it could still be valuable for a State to allow its citizens to do things that are not in and of themselves valuable at all. It could even be valuable for a State to allow its citizens to do things it would be better they did not do.

Now it is worth pausing for a moment, for someone might argue that the only reason that allowing citizens to defend themselves is valuable is that acts of self-defense are themselves valuable. Indeed, there is a tradition in criminal law theory that sees self-defense, as well as the criminal law's other so-called "justification defenses," in these terms. ${ }^{82}$ This tradition seeks to derive the rationale for justification defenses from an overall conception of the criminal law as seeking to minimize social harm. Accordingly, where a defendant has benefited, rather than harmed, society, he should be able to assert a justification as a defense to his violation of the

${ }^{81}$ See DWORKIN, supra note 14, at xi (1977) (asserting that "[i]ndividual rights are political trumps held by individuals"). In an earlier note, however, I rejected the idea of rights as trumps, for I suggested that it might be permissible for the parent to infringe the property owner's right to have others keep off his land even if the parent only had strong reasons of utility, but no right, to cross the land. See supra note 39.

${ }^{82}$ See 1 RoBINSON, supra note $54, \S 24$ (a) ("When conduct is deemed justified, it is, by definition, conduct that creates a net benefit to society."). 
prohibition. ${ }^{83}$ Indeed, on this view, a justification simply marks the limits of the various offense definitions to which it applies.

The central difficulty for the social welfare approach to justification is not surprisingly the existence of self-defense among the justification defenses, and in particular, the availability of that defense against innocent aggressors. For it cannot be generally maintained that killing a child or a madman inflicts no social harm, or that social welfare would always be better served by preserving one's own life at the expense of the attacker in such situations. ${ }^{84}$ Would it really benefit society for a victim to turn a machine gun on a mob of very young children who have gained access to their parents' weapons? Turning from an act to a rule-utilitarian formulation does not improve matters much: there is no reason to think that a rule that allows the killing of innocent attackers by those they threaten would be preferable from the standpoint of social utility to a rule that did not. ${ }^{85}$ What the welfare theorist needs, then, is to revise his conception of the objects over which considerations of social welfare range: it is the State's interest in allowing individuals to act on the basis of the morally permissible interest they take in their own well-being that must be weighed against the reasons the State has for forbidding them from doing so.

Thus far I have claimed that the State has an interest in giving broad scope to the moral permission that individuals have to act on their preferences for their own lives and bodily integrity. I have not, however, suggested in what that interest consists. Let me now offer a second claim: The State would enfeeble its authority were it to forbid its citizens from acting on reasons of this sort where there is no compelling countervailing reason to forbid it. A prohibition that significantly impaired each citizen's ability to

${ }^{83}$ See, e.g., Paul H. Robinson, A Theory of Justification: Societal Harm as a Prerequisite for Criminal Liability, 23 UCLA L. REV. 266, 291-92 (1975) (presenting "a new theory of the principle of justification .... [which] excludes from the jurisdiction of the criminal law those cases where a defendant engages in conduct which the code prohibits, but which ... does not in fact harm society or its members and which therefore should not be prohibited or punished"). The model for this conception of justification is the necessity defense: a person who burns down a field to create a firebreak in order to prevent a town from being consumed by fire violates the law in order to improve social welfare. Since the property law he violated has social welfare as its aim, the actor arguably has not done anything that the prohibition was intended to discourage.

${ }^{84}$ The account is more convincing where culpable aggressors are concerned.

${ }^{85}$ Such a rule might be defended on the grounds that it is not always easy to tell whether one's attacker is insane or mistaken. But the epistemic argument is difficult to apply to infantile aggressors, whose diminished capacity is likely to be readily apparent to those they attack. Sanford H. Kadish has amply detailed the objections to the idea that we can account for selfdefense by saying that "the life of the victim is of greater value than that of the attacker" in his Respect for Life and Regard for Rights in the Criminal Law, 64 CAL. L. REV. 871, 882 (1976). 
defend his own life without a strong, principled basis for its adoption would lack normative authority for those who must live by its rule. This is not particular to the interest agents have in their own preservation. A law mandating driving on the right would similarly lack normative authority if the interference with personal preference were not justifiable in terms of some readily identifiable public good. For the most part, however, there is no difficulty respecting the authority of the State to legislate traffic laws, for the State's interest in coordinating a dangerous activity is very high, indeed significantly higher than any interest it would normally have in forbidding selfdefensive conduct.

We still seem to have stopped short, however, of arguing that the State has an obligation to extend a right of self-defense to its citizens. Why, after all, does the fact that the State would damage its own authority by overregulating the liberties of its citizens suggest an obligation on the State's part not to overregulate? How can what appears to be a prudential consideration for legislators supply a limitation on the sorts of laws it is legitimate for a State to enact? The question we must now ask, and only partially begin to answer, is whether the State has an obligation to protect its own normative authority. What follows is the outline of an argument that says it does.

A State lacking in normative authority must rule to a great extent by coercion and force, rather than by persuasion and appeal. In the absence of normative authority, that is, the State must limit the liberties of its citizens quite sharply, since it cannot trust them to conform to the dictates of law without the constant threat of sanction. A State that possesses such authority, by contrast, can leave more to self-regulation. It is only at the margins that compliance with the law will require physical restraint. In short, a State that has preserved its normative authority can legislate in a way that gives maximum scope to the liberties of its citizens. Since citizens have an interest in living in a regime with more liberty rather than less, they also have a reason to prefer a State that preserves its authority by respecting their liberties.

Philosophers often conceive of law's authority as coercive. It is not surprising, then, that many also think that the reason the State ought not to outlaw self-defense is that it could not expect conformity to its dictates if it did. Jeremy Bentham, for example, argues that punishment should not be inflicted where the agent was under "the predominant influence of some opposite cause upon the will," such as in cases of physical danger or threat- 
ened harm by another person. ${ }^{86}$ The explanation he offers for this is that punishment in such cases would be ineffectual, since the conduct in question is not deterrable. If Bentham's thought rests on the general proposition that we cannot expect conformity to a law to which it would not be in an agent's interest to conform, however, the claim is too strong. ${ }^{87}$ The point of thinking of law as having normative authority is that an agent may conform because she regards herself as bound. She may accept the law, in H.L.A. Hart's terminology, from the "internal point of view." necessary for ordinary citizens to accept the law in this way; only the relevant officials need see themselves as bound. But even if Hart was right to think that a mature system of law does not depend on a pervasive acceptance of law from the internal point of view, he would probably have thought a regime in which such acceptance were widespread as better than one in which it were not. For such a regime is one in which citizens can be left at greater liberty.

While it is not surprising that Bentham thinks conformity to law depends on a congruence between obedience and self-interest, it is somewhat surprising to see Kant making a similar argument. He writes:

[T] here can be no penal law that would assign the death penalty to someone in a shipwreck who, in order to save his own life, shoves another, whose life is equally in danger, off a plank on which he had saved himself. For the punishment threatened by the law could not be greater than the loss of his own life. A penal law of this sort could not have the effect intended, since a threat of an evil that is still uncertain (death by judicial verdict) cannot outweigh the fear of an evil that is certain (drowning).

Kant of course drew a sharp distinction between duties of justice and duties of virtue, or for our purposes, legal and moral obligations, and his point here is meant to apply in the former realm. This does not solve the difficulty, however, because the passage suggests that conformity to the law, as such, could not be the subject of a moral duty. For if there were a moral duty to follow the law, Kant would surely want to say that a moral person could conform to the law even in the face of a strong inclination to

86 JeREMY BENTHAM, The PrINCIPLES OF MORALS AND LEGISLATION § 3, at 174 (Hafner Publ'g Co. 1948) (1823).

87 The argument is weak for another reason that we touched on above: punishment can always be made worse. One could, for example, add torture and humiliation to death. See supra note 16 . In theory, then, any conduct can be deterred. Bentham, however, apparently did not notice this point.

${ }^{88}$ H.L.A. HART, THE CONCEPT OF LAW 89 (2d ed. 1994) (explaining the notion of an "internal point of view").

89 IMMANUEL KANT, The Metaphysical First Principles of the Doctrine of Right, in THE METAPHYSICS OF MORALS 60 (Mary Gregor trans., Cambridge Univ. Press 1991) (1785). 
the contrary. Indeed, Kant would have to allow that conformity to the law would be all the more worthy if it flew in the face of self-interest. For a virtuous person would obey the moral obligation to follow the law, regardless of whether it was in his interest to do so.

If it is possible for the law to operate more by persuasion than by force, it is plausible to think the State has a duty to refrain from unduly burdening the permissible interest an agent takes in her own welfare. The argument for this claim is not a moral one, as it is on a Lockean picture of rights. Nor can the act of self-defense be directly vindicated by considerations of utility. Rather, it is an argument about the conditions of political legitimacy for a liberal state: a liberal state should seek to preserve its normative authority by giving as broad scope as possible to the liberties of citizens while maintaining respect for their rights and maximizing their welfare. It is the interest of citizens in their own liberty that demands it.

\section{SOME FURTHER THOUGHTS: THE LEGAL RIGHT}

I have focused on the implications of different conceptions of the moral right to self-defense for the question of whether the State has an obligation to extend a legal right to the same. I have mostly omitted exploration of the legal right itself. As it turns out, however, the dominant theoretical treatment of the legal entitlement also takes a claim-right approach. Criminal law theorists conceive of self-defense as a justification, and they have the same picture of legal justification that philosophers have of the notion of moral right. A legal justification is an entitlement to do something that is stronger than a mere permission. It imposes restrictions on the otherwise permissible conduct of others, such as that no one may interfere with its exercise or that there is a right to third-party assistance. ${ }^{90}$ A legal excuse, by contrast, is roughly the idea of a moral permission: it suggests that the violation of the law is tolerable, even if not necessarily commendable, and consequently it is not deserving.of punishment. Where excuses are concerned, however, there is no entitlement to violate the law that can be asserted against the conflicting entitlements of other agents. ${ }^{91}$ In describing self-

${ }^{90}$ Legal theorists think that if a person has a justification defense for a given act, no one may interfere with its performance. See 1 ROBINSON, supra note 54, §36(a)(2) ("Where an aggressor has a justification defense, the proper rule is clear: justified aggression should never be lawfully subject to resistance or interference."); see also FLETCHER, supra note 45, $\S 10.1$.1. They also think that third parties may assist a first party in accomplishing a justified act, that is, that third party rights of assistance track the first party's justification. See supra note 54 .

91 Often the notion of a legal excuse is explained by saying that the excused conduct is still blameworthy. See FLETCHER, supra note 45, $\$ 10.3$ ("Interposing a claim of excuse concedes that there is a wrong to be excused."). I reject this formulation, however, because I 
defense as a justification, rather than as an excuse, legal theorists attempt to account for the same features of the defense that lead the moral philosopher to treat self-defense as a claim rather than a liberty right. Criminal law scholars generally favor this view of the legal right over the social welfare account we touched on earlier. ${ }^{92}$

In my view, however, the theorist who thinks of justification in terms of social welfare has grasped an important aspect of the criminal law correctly: both offenses and defenses should be understood against the background of a view of the criminal law as serving public purposes. That is, the criminal law serves primarily to protect and to vindicate the welfare of the State, conceived as having a certain structural independence from the welfare of its members. The rights-based view, by contrast, reflects a private conception of the criminal law, one that sees the criminal law as serving to protect and advance the interests of private citizens. One increasingly finds, for example, the advancement of a rights-based conception of self-defense among those who call for attention to a set of supposed rights on the part of victims. ${ }^{93}$ But on the traditional public conception of criminal law, individual victims have little more place in the process than other private citizens do. ${ }^{94}$ The point of the criminal sanction is not for individual victims to find vindication through a state-supplied mechanism for redress, but rather for the State to advance its interests as guardian of the common good. ${ }^{95}$

It is important to stress, however, that the advancement of public interest involved in granting a legal right to self-defense is indirect; it is, in the first instance, the individual's good that the right advances. The public good is advanced only because, under the circumstances, it is in the public's interest to allow individuals to advance their own good. Defenses such as law enforcement and public necessity, by contrast, must be explained differently. A policeman's entitlement to make a lawful arrest represents a determination by the State that the public good requires the arrest, not merely that it is in the public's interest to refrain from prohibiting it. The difference

think it is both unclear what is meant by saying that the conduct is wrong or blameworthy in this context and because there seem to be instances in which the claim, on any reasonable formulation, is false. Someone who participates in a nonviolent crime because of a threat of serious injury to a loved one has an excuse of "duress," but it would surely be wrong to describe his conduct as blameworthy.

92 See supra note 82 and accompanying text (explaining the theory that citizens should be allowed to defend themselves because the acts of self-defense are themselves valuable).

93 See, e.g., GeORge FletCher, WITH Justice fOR SOME: PROTECTING Victims' RIGHTS IN CRIMINAL TRIALS 188 (1995).

${ }^{94}$ Their special role, if any, is limited to their usefulness as witnesses.

95 I develop these considerations further as they apply to the theory of offense definition in Claire O. Finkelstein, Positivism About the Notion of an Offense, 87 CAL. L. REV. (forthcoming 1999) (manuscript on file with author). 
between the two cases is apparent from the fact that while it may be in the State's interest to refrain from forbidding self-defense in certain situations, it would presumably never be in the State's interest to require it. A police officer's actions, by contrast, are not merely too costly to prohibit-they are themselves required by a correct evaluation of what the public interest requires.

Elsewhere, I have distinguished self-defense from the law's other justifications by suggesting that self-defense might be thought an excuse rather than a justification. ${ }^{96}$ I have argued that self-defense is not in principle different from duress and other "personal necessity" defenses, typically thought of as excuses. ${ }^{97}$ The view of self-defense as a liberty right in morals and as an excuse in law are not mutually entailing. It would be possible, for example, to think the moral entitlement a mere permission at the same time that one regarded the legal entitlement as a justification. Both in morals and in law, however, the weaker view of the entitlement makes more sense when one also adopts the broad view of self-defense we have considered.

${ }^{96}$ See generally Finkelstein, supra note 45 . At least one other commentator appears to support the position as well. See Cathryn Jo Rosen, The Excuse of Self-Defense: Correcting a Historical Accident on Behalf of Battered Women Who Kill, 36 AM. U. L. REV. 11, 17 (1986) (arguing "that classifying self-defense as an excuse will result in more justice for battered women who kill without threatening important values promoted by the criminal law, such as the suppression of private retaliation and the sanctity of human life"). Some scholars accept self-defense as an excuse for some subset of the cases in which the defense applies. See, e.g., Larry Alexander, Self-Defense, Justification, and Excuse, 22 PHIL. \& PUB. AFF. 53, 64-65 (1993).

97 In particular, I called defenses like self-defense and duress "rational" excuses. See Finkelstein, supra note 45 , at 623 . This is because they apply to intentional actions and depend on the content of an agent's reason for acting. They are thus manifestly unlike the excuses of insanity or infancy, where the excusing condition exonerates because it suggests that the conduct is less than fully rational. 